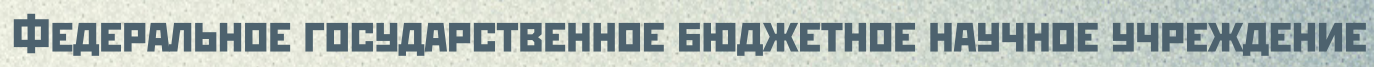

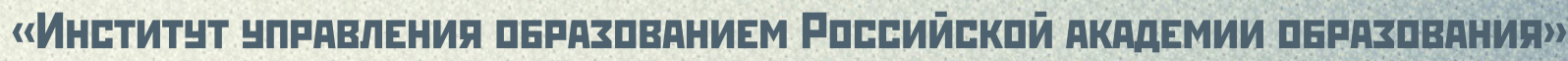

Галкина А.И., Бобкова Е.Ю., Бурнашева Е.А., Гришан И.А., Кадырова Э.А.

\title{
METロA口ЛロГИЧЕСКИЙ ИНСТРУМЕНТАРИЙ
} 口ЦЕНКИ НОВИЗНЫ ПРОИЗВЕДЕНИЙ НАНКИ В ФवРМЕ

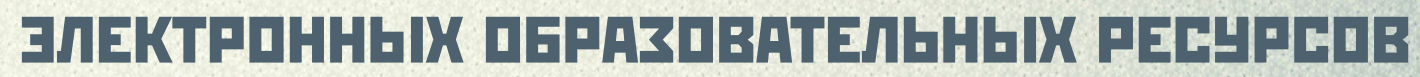

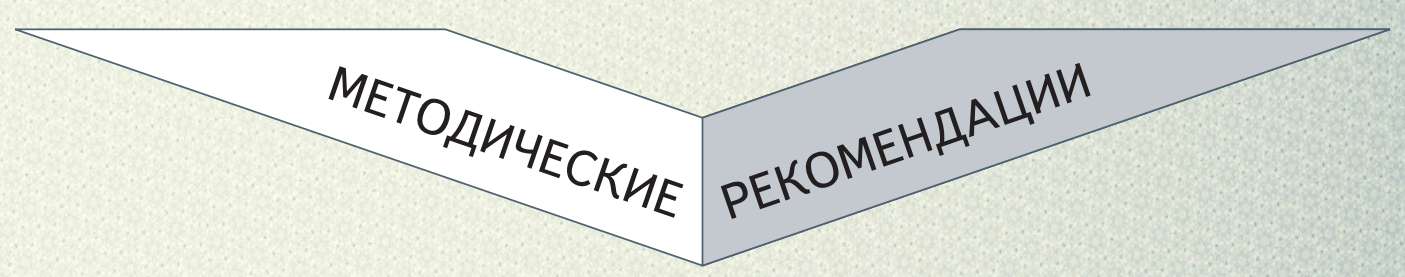


Министерство образования и науки Российской Федерации

Федеральное государственное бюджетное научное учреждение "Институт управления образованием Российской академии образования"

Галкина А.И., Бобкова Е.Ю., Бурнашева Е.А., Гришан И.А., Кадырова Э.А.

Методологический инструментарий оценки новизны произведений науки в форме электронных образовательных ресурсов

Методические указания

Science and Innovation Center Publishing House Saint-Louis, Missouri, USA 
УДК 37

ББК Р75

ГРНТИ 14.01.11

Методологический инструментарий оценки новизны произведений науки в форме электронных образовательных ресурсов: Методические указания / А.И. Галкина, Е.Ю. Бобкова, Е.А. Бурнашева, И.А. Гришан, Э.А.Кадырова. - St. Louis, Missouri, USA: Science and Innovation Center Publishing House. -38 p.

\section{ISBN 978-0-615-67236-6}

\section{doi: 10.12731/OFERNIO.2017.38}

Настоящие Методические указания посвящены отраслевой регистрации произведений науки, поддерживающих образовательный процесс подготовки высококвалифицированных кадров, отвечающих требованиям современного мира, а также инструментарию оценки новизны произведений науки в форме электронных образовательных ресурсов.

ISBN 978-0-615-67236-6

(С) Галкина А.И., Бобкова Е.Ю., Бурнашева Е.А., Гришан И.А., Кадырова Э.А., 2017

(С ФГБНУ “ИУО РАО”, 2017 


\section{Оалавление}

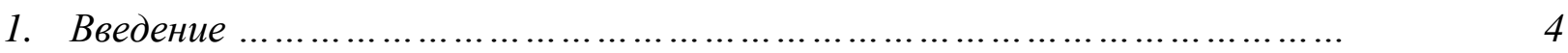

2. Нормативно-правовое и организациионо-распорядительное обеспечение.......... 5

3. Методологическое обеспечение ..................................................

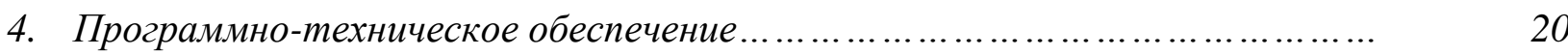

5. Информационное обеспечение ............................................

6. Пошаговая инструкция оценки новизны электронного образовательного

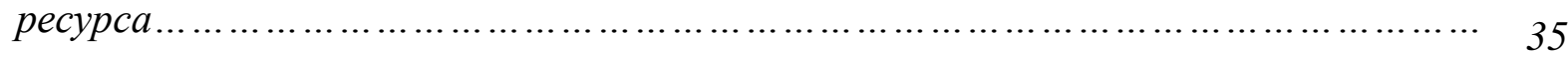

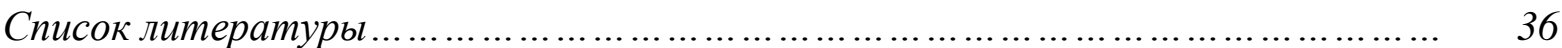




\section{1. Введение}

Настоящие методические рекомендации разработаны в рамках проекта «Нормативно-правовое регулирование отношений в сфере образования и отраслевая регистрачия произведений науки» (27.9383.2017/БЧ) на 2017 год. Методические рекомендации предназначень для научно-педагогической общественности, в иелях ознакомления их с процедурой оценки новизнь в рамках отраслевой регистрации произведений науки в форме электронных образовательных ресурсов, и специалистов в области оченки электронных образовательных ресурсов. Аккумулированный в Объединенном фонде электронных ресурсов «Наука и образование» опыт по оченке новизны произведений науки в форме электронных образовательных ресурсов, описан в многочисленных трудах этого года, воплощен в практике оценки 40000 электронных ресурсов 745 организаций и учреждений, более 60000 авторов данных разработок.

Объект исследования: образовательные учреждения

Предмет исследования: произведения науки в форме электронных образовательных ресурсов.

Методы исследования: статистический, аналитический, экспертный, абстрагирование, дедукиия 


\section{2. Нормативно-правовое и организационно-распорядительное обеспечение}

1. Приказ Министерства образования и науки Российской Федерации от 09.11.2016 г. № 1399 «О внесении изменений в показатели мониторинга системы образования, утвержденный приказом Министерства образования и науки Российской Федерации от 15 января 2014 г. № 14», в соответствии с которым в перечень показателей проводимого мониторинга образовательных учреждений включается показатель «наличие собственных электронных образовательных и информационных ресурсов».

2. Постановление Правительства Российской Федерации № 376 от 31 марта 2017 года, в соответствие с которым в структуру государственной программы «Развитие образования» интегрируется ряд приоритетных проектов по направлению стратегического развития «Образование», в том числе проект «Современная цифровая образовательная среда в Российской Федерации». Цель проекта - создать к 2018 году условия для системного повышения качества и расиирения возможностей непрерывного образования для всех категорий граждан за счет развития российского цифрового образовательного пространства.

3. Постановление от 25 августа 2017 года №1007. Внесены изменения в Правила управления государственными заказчиками правами Российской Федерации на результаты интеллектуальной деятельности гражданского, военного, специального и двойного назначения. Это расширит возможности коммерциализации результатов интеллектуальной деятельности, права на которые принадлежат Российской Федерации.

4. Авторское право - институт гражданского права, регулирующий правоотношения, связанные с созданием и использованием (изданием, исполнением, показом и т. д.) произведений науки, литературы или искусства, то есть объективных результатов творческой деятельности людей в этих областях. Программы для ЭВМ и базы данных также охраняются авторским правом. Они приравнены к литературным произведениям и сборникам, соответственно. Название "авторское право" является условным, так как закон регулирует и охраняет права "правообладателя", а не автора. (Режим доступа: https://ru.wikipedia.org/wiki/Авторское_право. Дата доступа 28.10.2017);

5. Проект «Нормативно-правовое регулирование отношений в сфере образования и отраслевая регистрация произведений науки» 27.9383.2017/Б на 2017 год. (Режим доступа http://госзадание.pф/2016/competitions. Дата доступа 28.10.2017);

6. Информационное письмо ФГБНУ “Институт управления образованием Российской академии образования»

(Режим доступа http://ofernio.ru/portal/status/info_pismo_rao.jpg · Дата доступа 31.10.2017)

7. Приказ ФГБНУ “Институт управления образованием Российской академии образования» № 79 от 14.04.2015 г. http://ofernio.ru/portal/docs/prikaz_79.jpg . Дата доступа 28.10.2017.) 
8. Положение Объединенного фонда электронных ресурсов «Наука и образование» (Режим доступа: http://ofernio.ru/portal/docs/polojenie_ofernio.doc Дата доступа: 28.10.2017). 


\section{2. Методологическое обеспечение}

Электронные образовательные ресурсы являются подвидом произведений науки. Произведения науки наряду с произведениями литературы и произведениями искусства являются разновидностями результатов интеллектуальной деятельности:

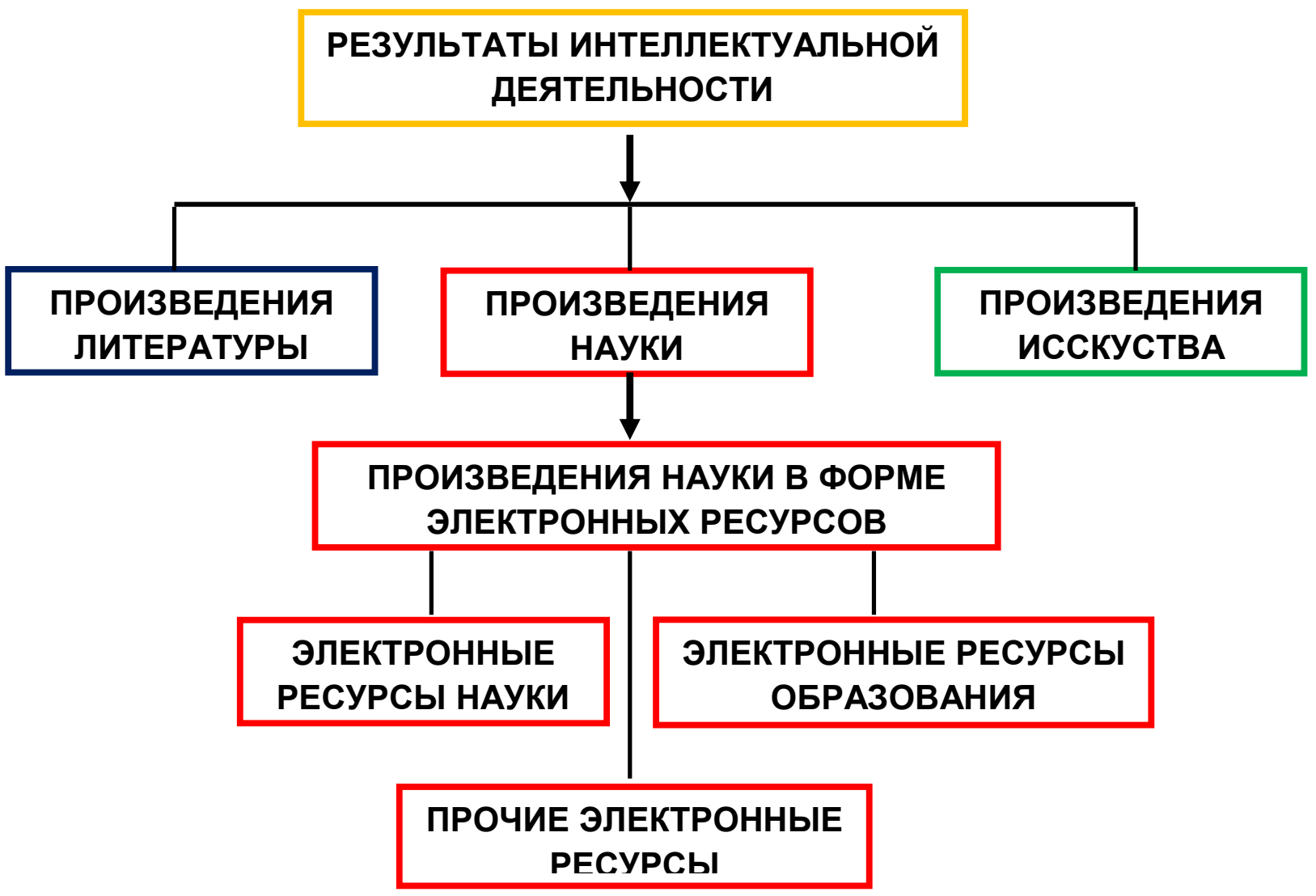

Рис. 1 Подвиды результатов интеллектуальной собственности

Потребность в оценке новизны электронных образовательных ресурсов, т.е. исключение дублирования, копирования и заимствования ЭОР университетами друг у друга, вызвана тем обстоятельством, что разработка электронных образовательных ресурсов университетами осуществляется по совпадающим:

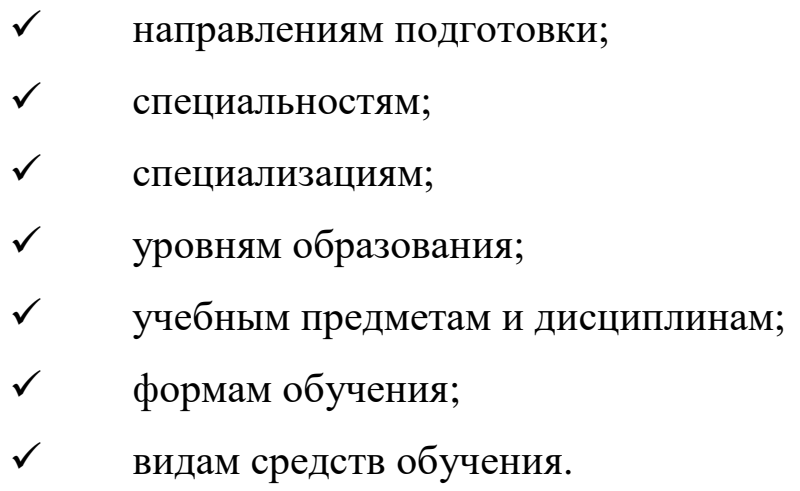

Подход к оценке новизны электронного образовательного ресурса базируется на применимости авторского права на литературные произведения и авторского права на 
произведения науки, и, как следствие этого, тождественности общих характеристик литературного произведения и ЭОР.

Таблица 1. Тождественность характеристик произведения литературы, произведения науки и электронных образовательных ресурсов - подвида произведений науки

\begin{tabular}{|l|l|l|}
\hline $\begin{array}{l}\text { Характеристика } \\
\text { произведения литературы }\end{array}$ & $\begin{array}{l}\text { Характеристика } \\
\text { произведения науки }\end{array}$ & $\begin{array}{l}\text { Характеристика электронного } \\
\text { образовательного ресурса }\end{array}$ \\
\hline ФИО автора/авторов & ФИО автора/авторов & ФИО автора/авторов \\
\hline название & название & наименование \\
\hline место издания & место разработки & место разработки \\
\hline дата издания & дата завершения & дата завершения разработки \\
\hline язык & язык & $\begin{array}{l}\text { инструментальные средства } \\
\text { разработки }\end{array}$ \\
\hline форма & форма & форма \\
\hline
\end{tabular}

Для электронных образовательных ресурсов - подвида произведения науки, его форма имеет немалое значение, так как определяет этап обучения, объем учебного материала, форму обучения и т.д., например;

первом этапе обучения по очной, заочной, очно-заочной формам обучения;

- уцебно-методический комплекс “Информационная безопасность" сочетание учебного материала и методического материала, например включающего: рекомендации по выполнению практического задания и его оформления (для второго этапа обучения - углубленного, продвинутого; по очной, заочной, очно-заочной формам обучения);

- м массовый обучающий онлайн-курс “Информационная безопасность" учебный материал для дистанционной формы обучения + система регистрации обучаемых, система контроля выполнения заданий, система промежуточного и итогового контроля знаний и т.д.

На этом примере демонстрируется, как форма ЭОР соответствует форме обучения (очное, очно-заочное, заочное, дистанционное), этапу обучения (начальное, углубленное, продвинутое).

Многообразие форм ЭОР, фиксируемых сегодня, представлено на портале фонда, где приведено почти 700 разновидностей ЭОР. Поэтому при оценке новизны электронных образовательных ресурсов рассматривается вся совокупность его общих характеристик: 
ФИО автора/авторов, наименование, место разработки, дата завершения разработки, инструментальные средства разработки, форма ресурса.

Отраслевая регистрация ЭОР и его предварительная оценка новизны осуществляются на основании рассмотрения комплекта электронных документов (КЭД), описывающих электронный образовательный ресурс без предъявления разработчиками самого электронного образовательного ресурса и его рассмотрения.

Это вызвано тем, что электронные образовательные ресурсы, как правило, имеют единственную реализацию, с последующим размещением в закрытых локальных сетях образовательных учреждений, т.е. относятся к разновидности “непубликуемых документов".

Поэтому к комплекту электронных документов, описывающих ЭОР, предъявляются повышенные требования с позиций полноты, достаточности, достоверности содержания электронных документов.

На начальном этапе рассматривается состав полного комплекта электронных документов и оценивается качество самих электронных документов.

Обязательным является требование к авторам - предъявлять на рассмотрение комплект электронных документов, сгенерированный программой RegOFERNiO, что обеспечивает полноту комплекта документов, подлинность документов - авторство документов, соответствие формы документов заявленной форме собственности на ЭОР.

Объекты оценки данного этапа представлены на рисунке 2.
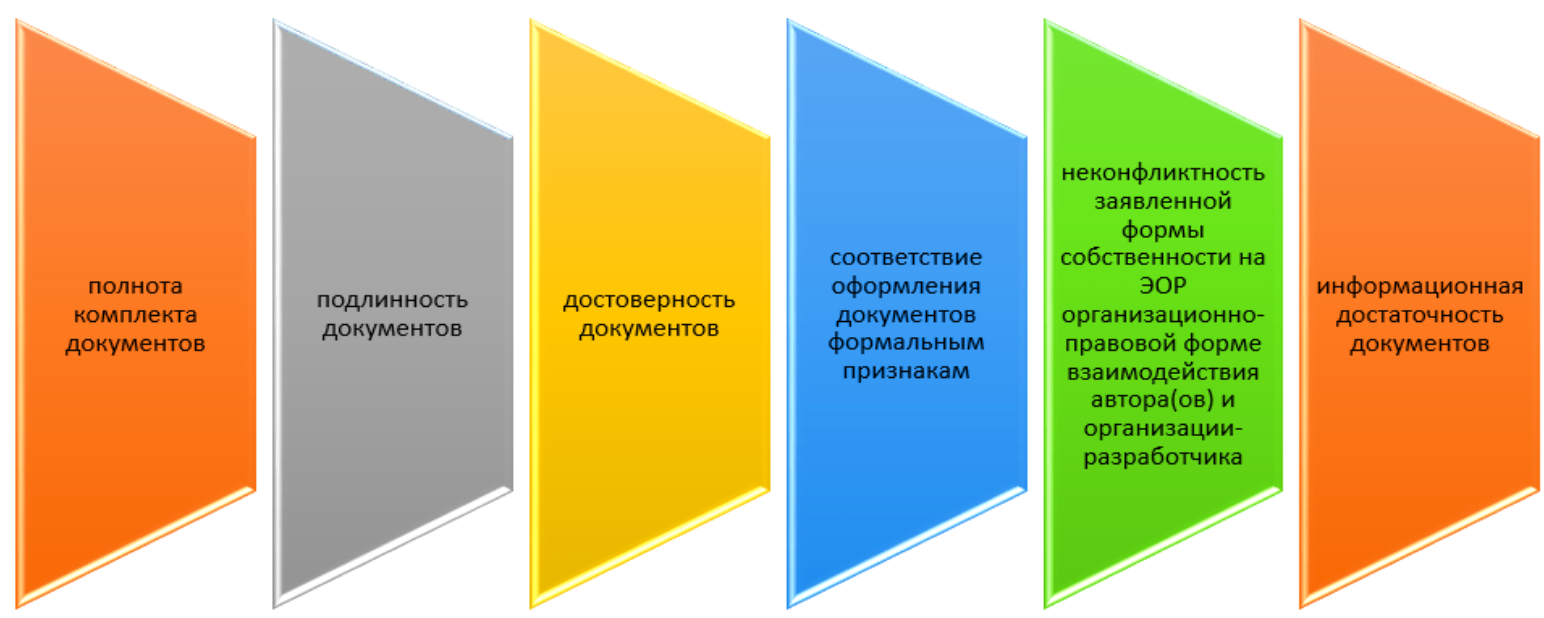

Рис. 2. Объекты оценки на этапе рассмотрения и оценки комплекта электронных документов (КД) на электронный образовательный ресурс

По итогам положительной оценки электронных документов осуществляется оценка новизны ЭОР посредством поиска аналогов данного электронного образовательного ресурса по базе данных ОФЭРНиО с оценкой приоритетности и потребительских свойств 
электронного образовательного ресурса. Ниже приведена обобщённая модель оценки электронных ресурсов.

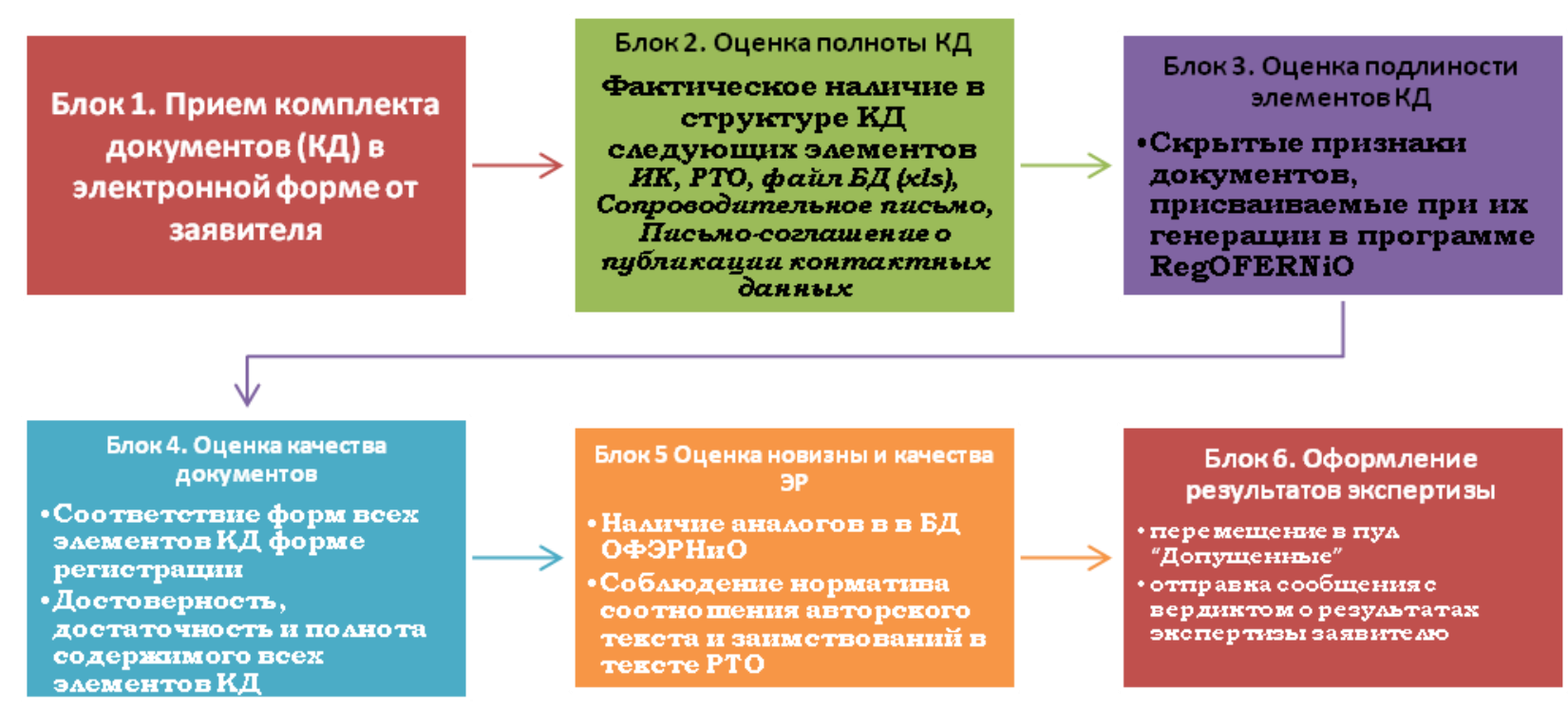

Рис. 3. Обобщенная модель оценки электронных ресурсов

Поиск аналогов электронного образовательного ресурса осуществляется обращением к базе данных фонда посредством Конструктора Запросов. Содержание запроса - совокупность общих характеристик ЭОР и ключевые слова, характеризующие содержание электронного образовательного ресурса (табл. 2). Форма запроса - форма Конструктора Запроса. С помощью Конструктора Запросов можно получить 87 видов различных отчетов.

Таблица 2. Номенклатура общих характеристик ЭОР

\begin{tabular}{|l|}
\hline Характеристика электронного образовательного ресурса \\
\hline ФИО автора/авторов \\
\hline наименование \\
\hline место разработки \\
\hline дата завершения разработки \\
\hline инструментальные средства разработки ЭОР \\
\hline форма \\
\hline ключевые слова \\
\hline
\end{tabular}




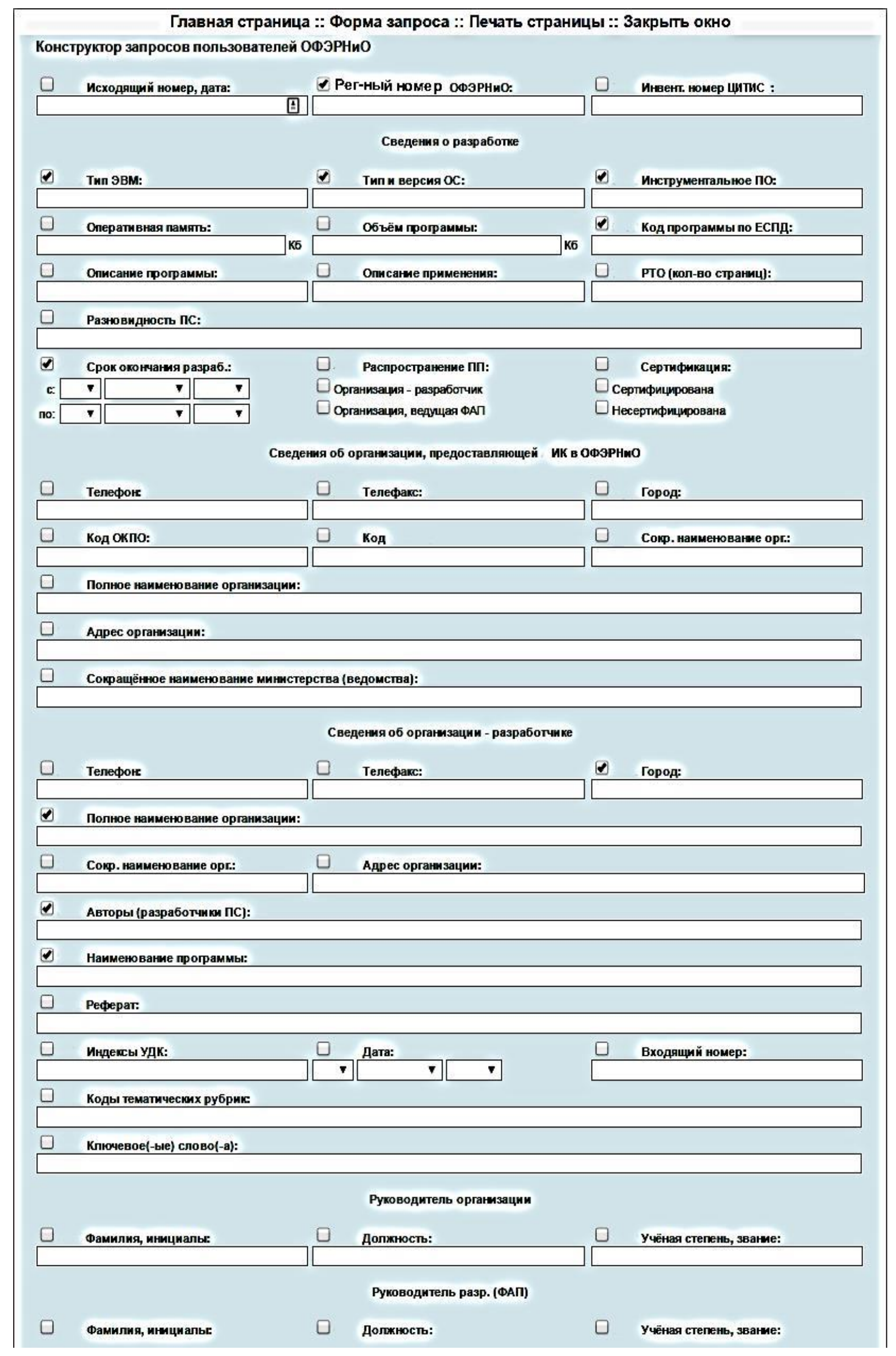




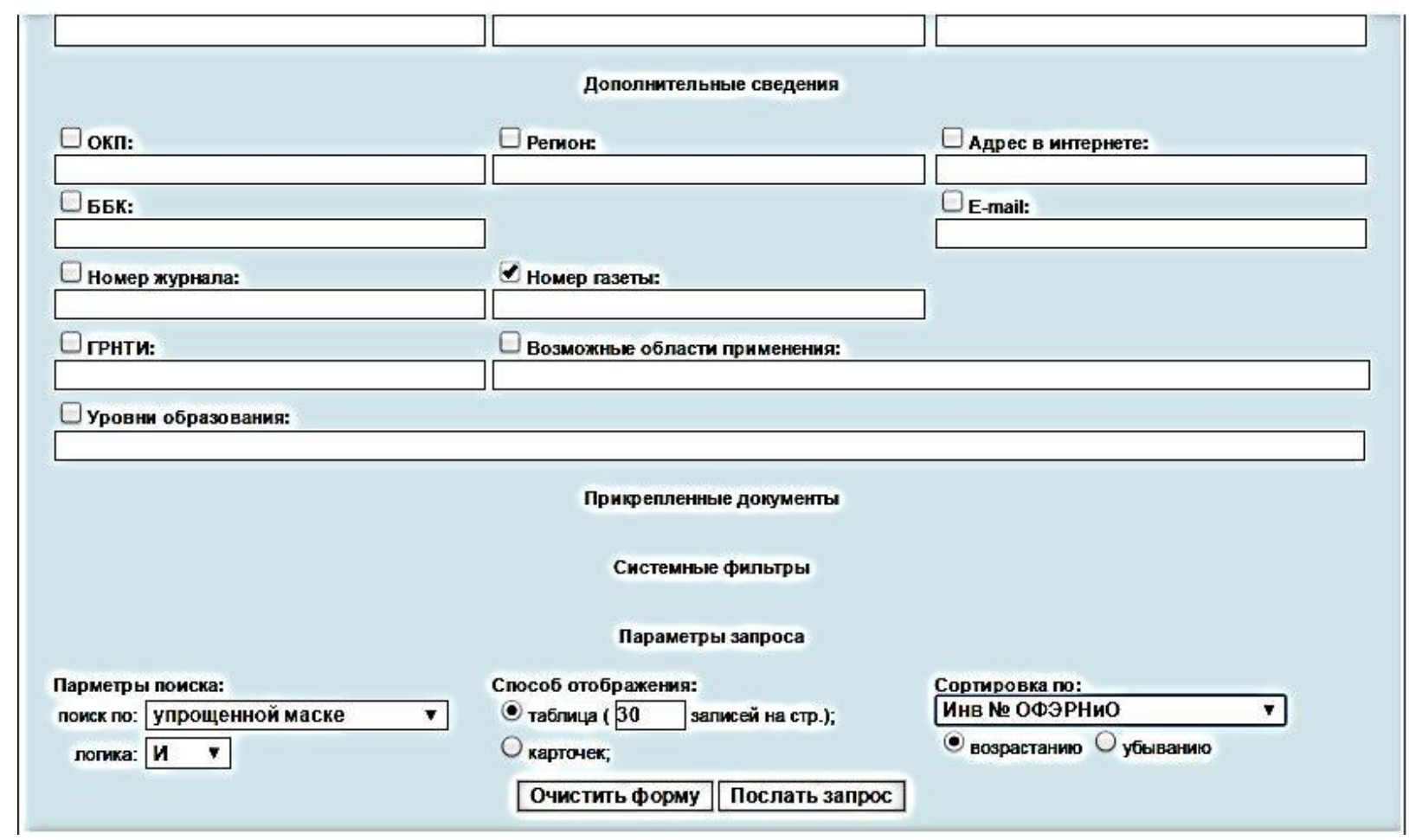

Рис.4 Общий вид Конструктора Запросов

Поиск посредством Конструктора Запросов на основании совокупности общих характеристик ЭОР реализуется через морфологический поиск.

Морфологический поиск организован:

$\checkmark$ без учёта морфологии слова, т.е. видоизменений (словоформ) слова по родам, числам, падежам, спряжениям и т.д.

$\checkmark$ в упрощенной форме - по “маске” слова или “упрощенной маске”, что, однако, не сказывается на полноте и точности поиска, например: поиск “Информационная” организован как поиск “Информационн”.

При поиске без учета словоформ допускается:

- использование любого регистра букв. Например: можно искать как “Иванов”, так и “иванов” - результат будет одинаков.

- использование специальных символов: символ \% (процент) в любом поле запроса заменяет любую последовательность любых символов; символ _ (подчеркивание) заменяет один любой символ.

- использование знака вертикальной черты “|”, который по логике заменяет логическое ИЛИ внутри любого поля запроса. Если в поле “Город", ввести “Иркутск|Ярославль”, то в результате будут найдены записи, о разработках из Иркутска или Ярославля. В одном поле может быть использовано любое количество связок ИЛИ например: “Иркутск|Ярославль|Омск|Рязань”. 
Ниже приведен протокол поиска аналогов ЭУМК “Химические реакции”, разработанного МГУ.

Следует обратить внимание, что поиск аналогов по базе данных, содержащей информацию 1998-2016 годов, осуществляется в течение долей секунды.

Главная страница :: Форма запроса : Химические реакции/ MS Office; Dispace/ электронный учебно-методический комплекс/Владимирова С.А./ Москва / 01.02.2017: Печать страницы :: Закрыть окно

Записей, удовлетворяющих вашему запросу, найти в БД не удалось.

Время исполнения: 0.020324945449829 сек.

Рис. 5 Протокол поиска аналогов ЭОР «Электронный учебно-методический комплекс Химические реакции"», разработанного МГУ.

Сравнение найденных аналогов и рассматриваемого ЭОР, в настоящее время, осуществляется экспертным и аналитическим методами.

Так как информация о ЭОР является слабоструктурированной - плохо поддающейся унификации, стандартизации, рубрикации и классификации информацией, поиск аналогов осуществляется морфологическим поиском, обеспечивающим интеллектуальный поиск и классификацию информации.

На втором этапе оценки новизны ЭОР рассматриваются его характеристики, обеспечивающие высокое потребительское качество и, следовательно, эффективность применения в образовательном процессе. Рассматриваются и анализируются ориентированно-пользовательские характеристики электронного образовательного ресурса: программно-технические характеристики; психолого-педагогические характеристики; эргономические характеристики (см. рис. 6.1-6.4.).

Оценка психолого-педагогических характеристик, в части педагогической составляющей, заключается в оценке совокупности педагогических, методических и дидактических компонент электронного образовательного ресурса.

И, если педагогическое содержание ЭОР стандартизировано, то методические решения всегда индивидуальны и оригинальны.

Дидактические решения базируются на целесообразности подачи учебного материала, в целях эффективности его изучения. 


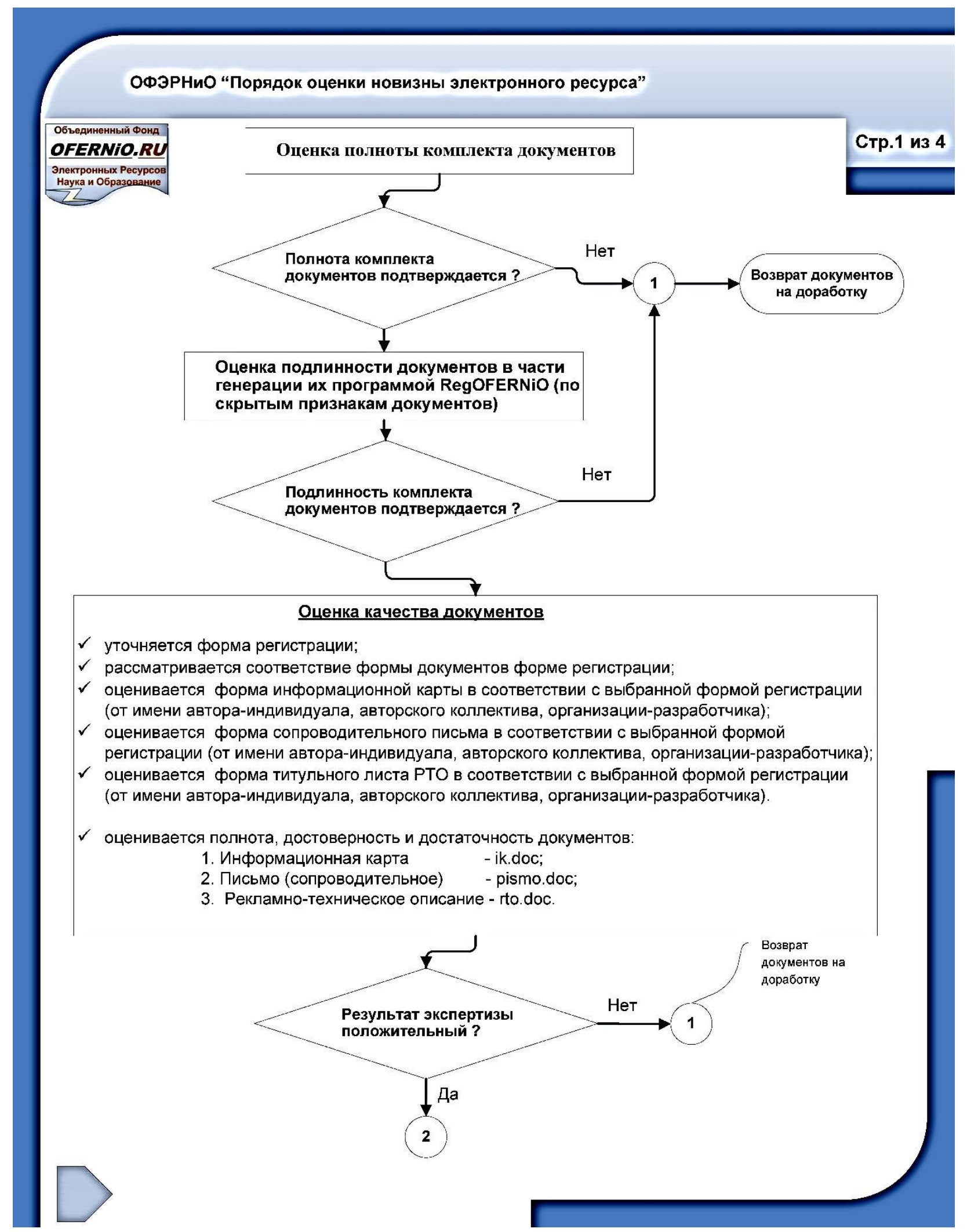

Рис. 6.1 Блок-схема процедуры “Порядок оценки новизны электронного ресурса”.

Начальный этап 


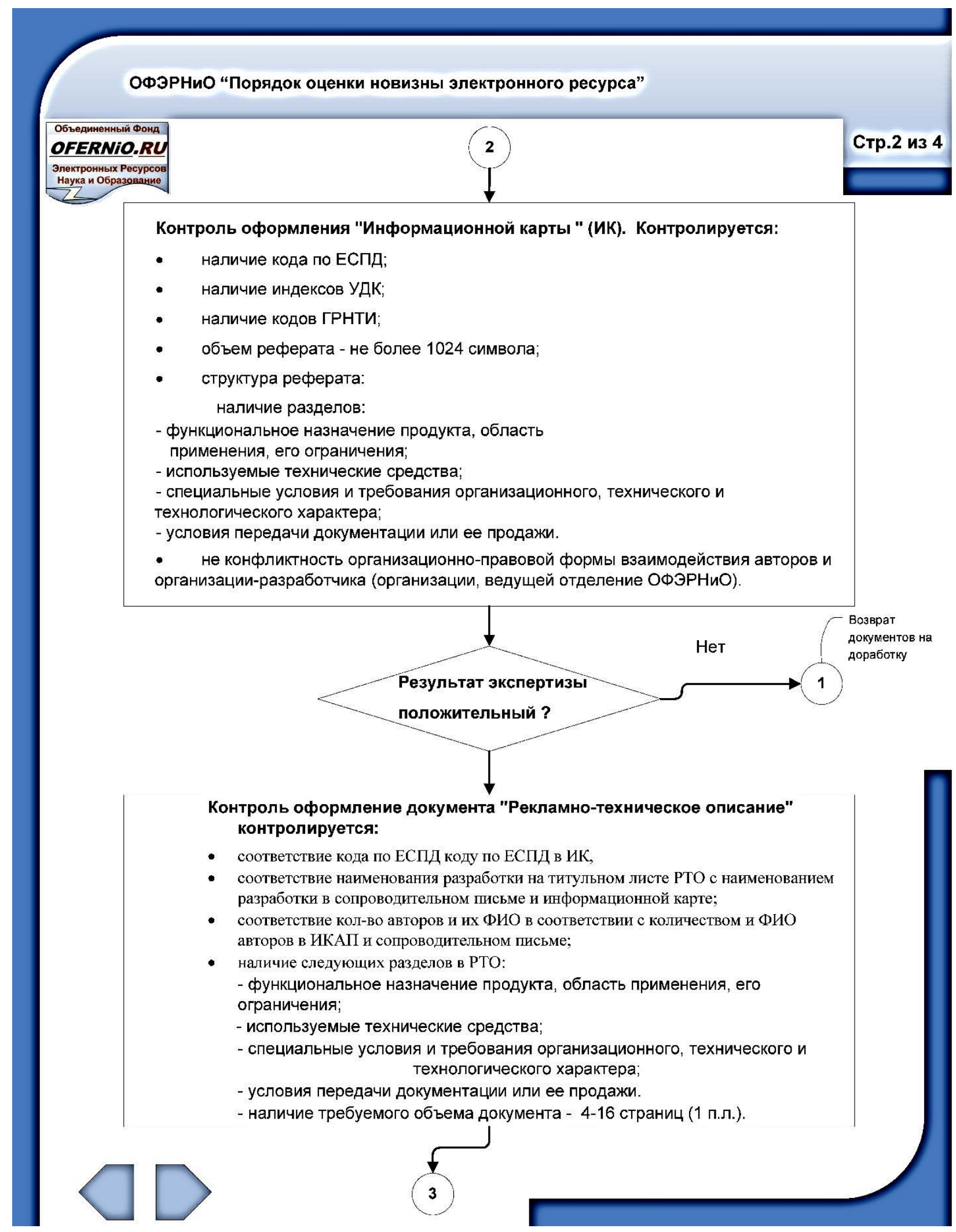

Рис. 6.2 Блок-схема процедуры “Порядок оценки новизны электронного ресурса”.

Промежуточный этап 1 


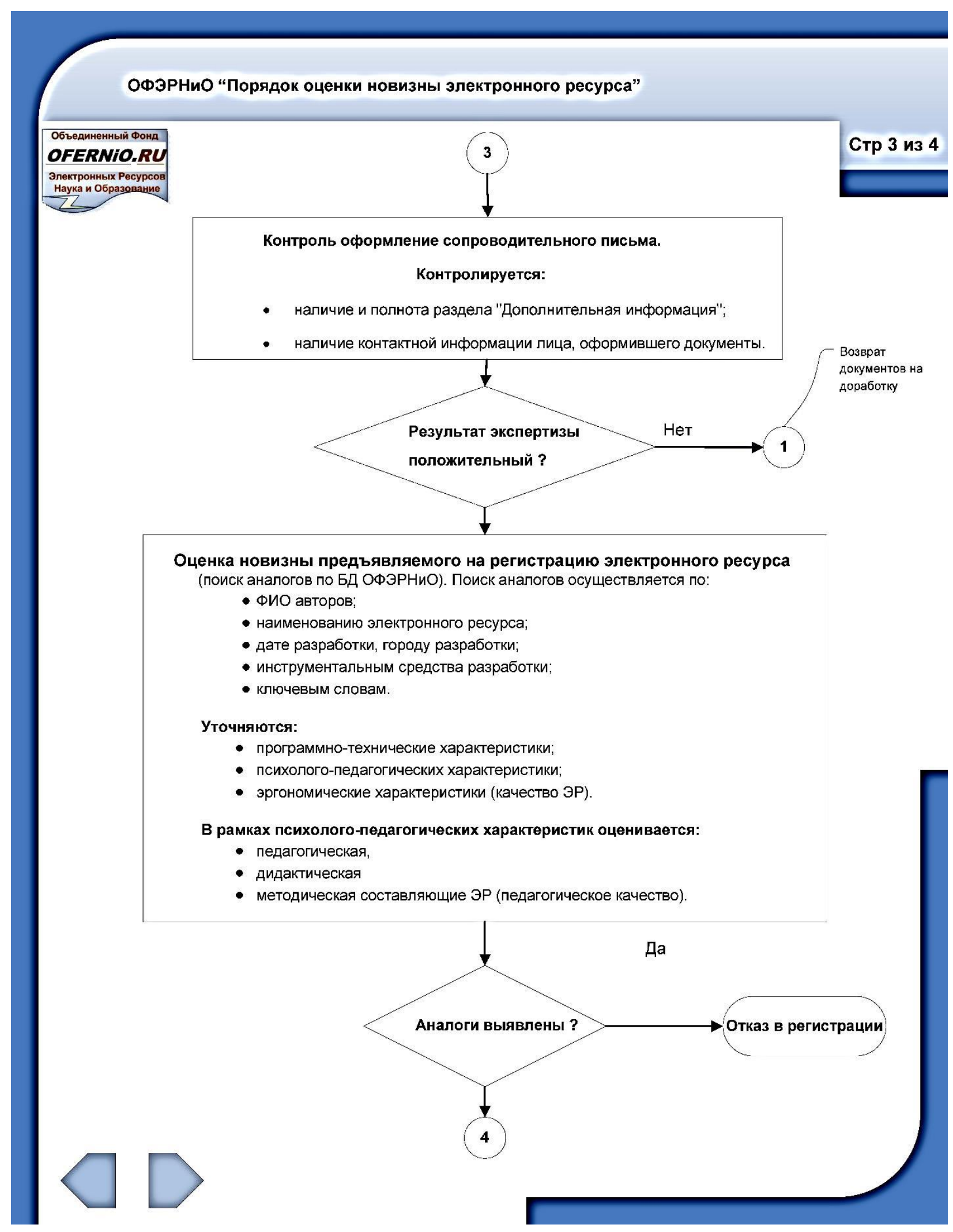

Рис. 6.3 Блок-схема процедуры “Порядок оценки новизны электронного ресурса”.

Промежуточный этап 2 


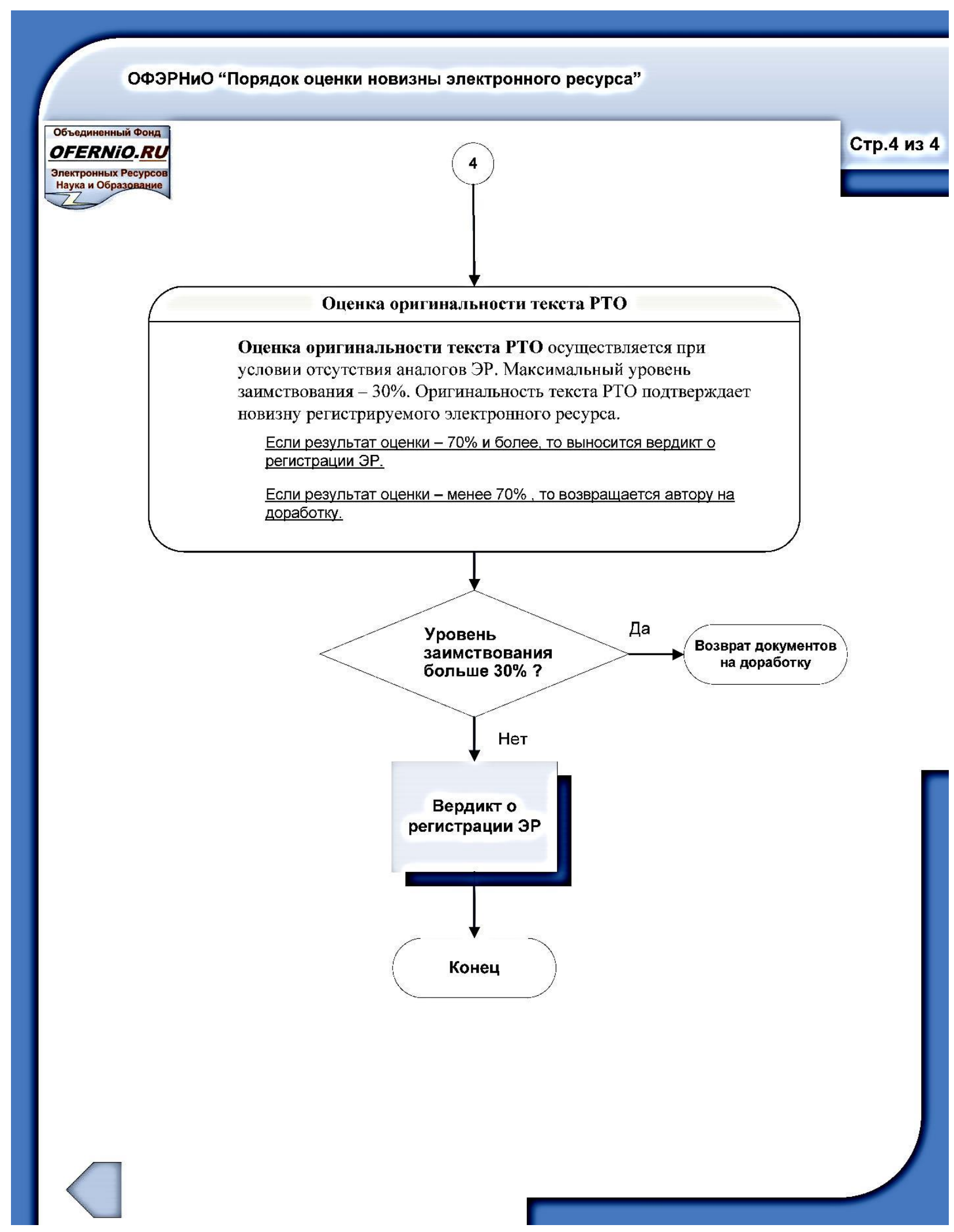

Рис. 6.4 Блок-схема процедуры “Порядок оценки новизны электронного ресурса”.

Заключительный этап 2

На рисунке 7 приведена модель оценки качества произведений науки в форме электронных образовательных ресурсов - модель ориентированно-пользовательских 
характеристик, по котором ведется сравнение и анализ в случае наличия аналогов рассматриваемого электронного образовательного ресурса:

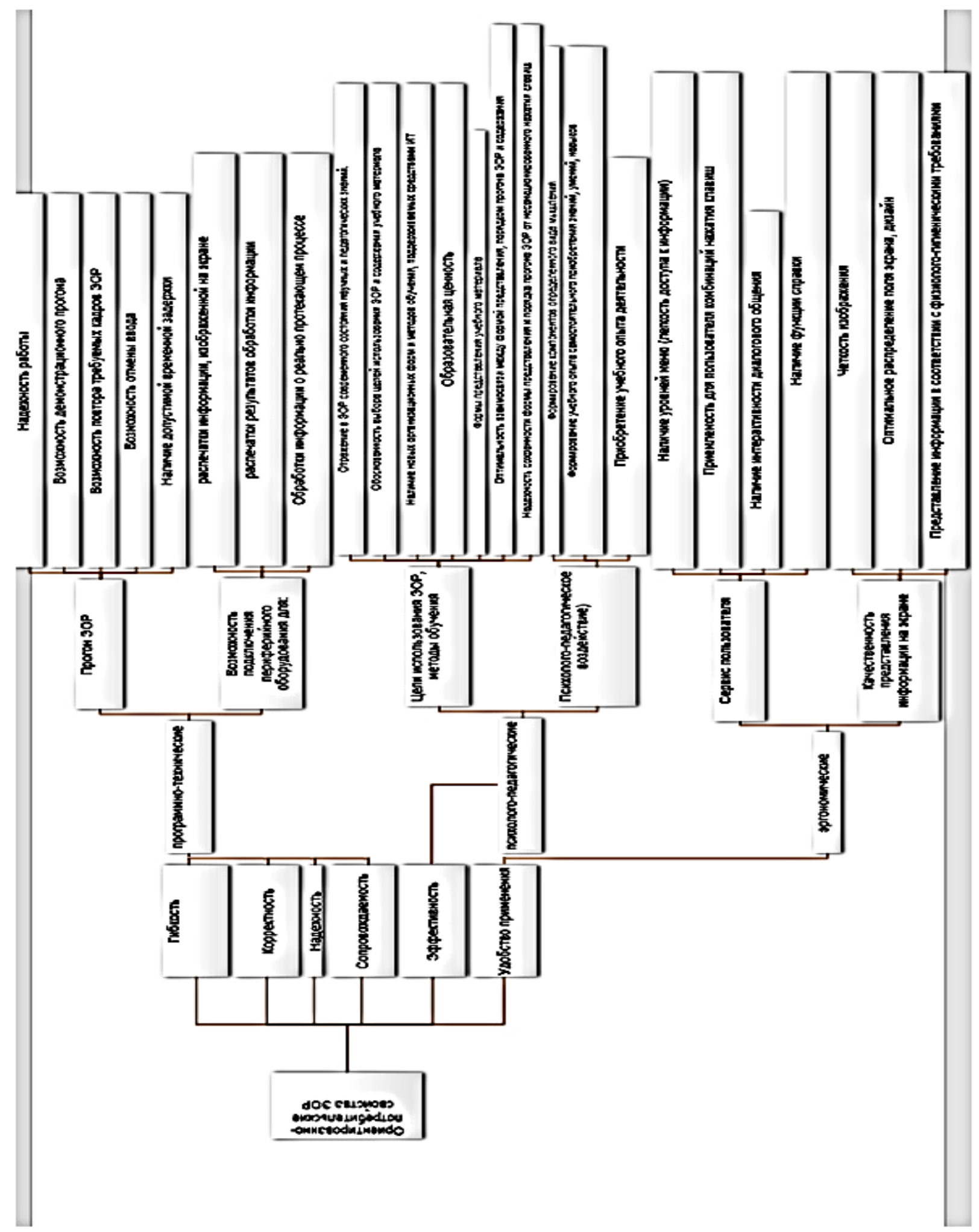

Рис. 7 Модель оценки качества произведений науки в форме электронных образовательных ресурсов 
На последнем этапе рассматривается оригинальность текста полноформатного документа “Рекламно-техническое описание” (далее - РТО) электронного образовательного ресурса в качестве «фискальной» операции оценки новизны электронного образовательного ресурса.

В качестве допустимого нижнего уровня чужих заимствований в тексте РТО ЭОР, отвечающего требованиям новизны, устанавливается уровень в $30 \%$.

Это положение является одним из зафиксированных выводов десятилетней научноисследовательской программы “Оценка качества программ для ЭВМ” (1980-1990 гг.).

Научно-исследовательская программа констатировала, что программа, отвечающая требованиям новизны, сопровождается описывающей ее документацией, оригинальность текста которой не ниже $70 \%$.

Этот вывод транспонирован на документы, описывающие электронные образовательные ресурсы.

Собственные электронные образовательные ресурсы, являясь компонентами информационно-образовательной среды образовательного учреждения, формируют его имидж и репутацию с научно-педагогической стороны, характеризуют научную активности его профессорско-педагогического состава.

Таким образом, ЭОР - это и показатель мониторинга образовательных учреждений при их аттестации и лицензировании (на этапе определения типа образовательного учреждения), и показатель аттестации научно-педагогического персонала при выдвижении на ученое звание. 


\section{4. Программно-техническое обеспечение}

4.1. Так как информащия о электронных образовательных ресурсах в силу множественности их форм, является слабоструктурированной, т.е. плохо поддающейся стандартизаџฺи, унификаџии, и в следствии этого, плохо подается классификации и рубрикации, введено жесткое правило оформления и генерации документов при помощи программы автоматизации подготовки регистрационных документов для регистрации ОФЭРНиО

RegOfernio_v_3_3.zip (28.09.2017 2.), размещенной по ссылке http://ofernio.ru/portal/files.php (ссылка ПРОГРАММЫ в горизонтальном меню) 


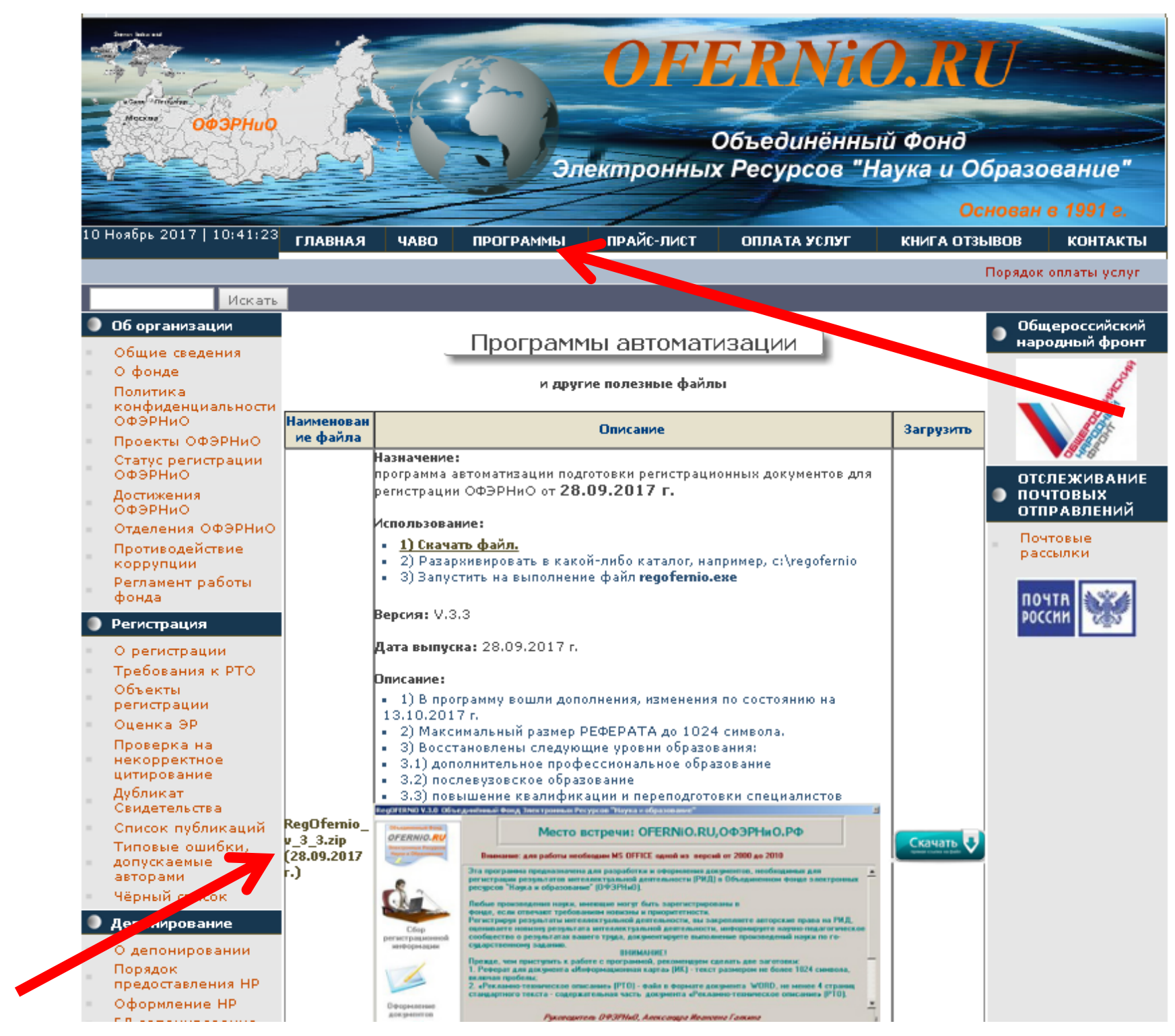

Рис. 8 Скриншот странищы ПРОГРАММЫ для скачивания программы программа автоматизацчии подготовки регистрациионных документов RegOFERNiO

Рекомендуется скачать последнюю версию программы, разархивировать ее и запустить файл со значком “ $i$ ”.

Перед разработчиком откроется несколько экранов с окошками, которые надо заполнить, ориентируясь на всплывающце подсказки, и, обращцаясь к многочисленным структурированным справочникам. 


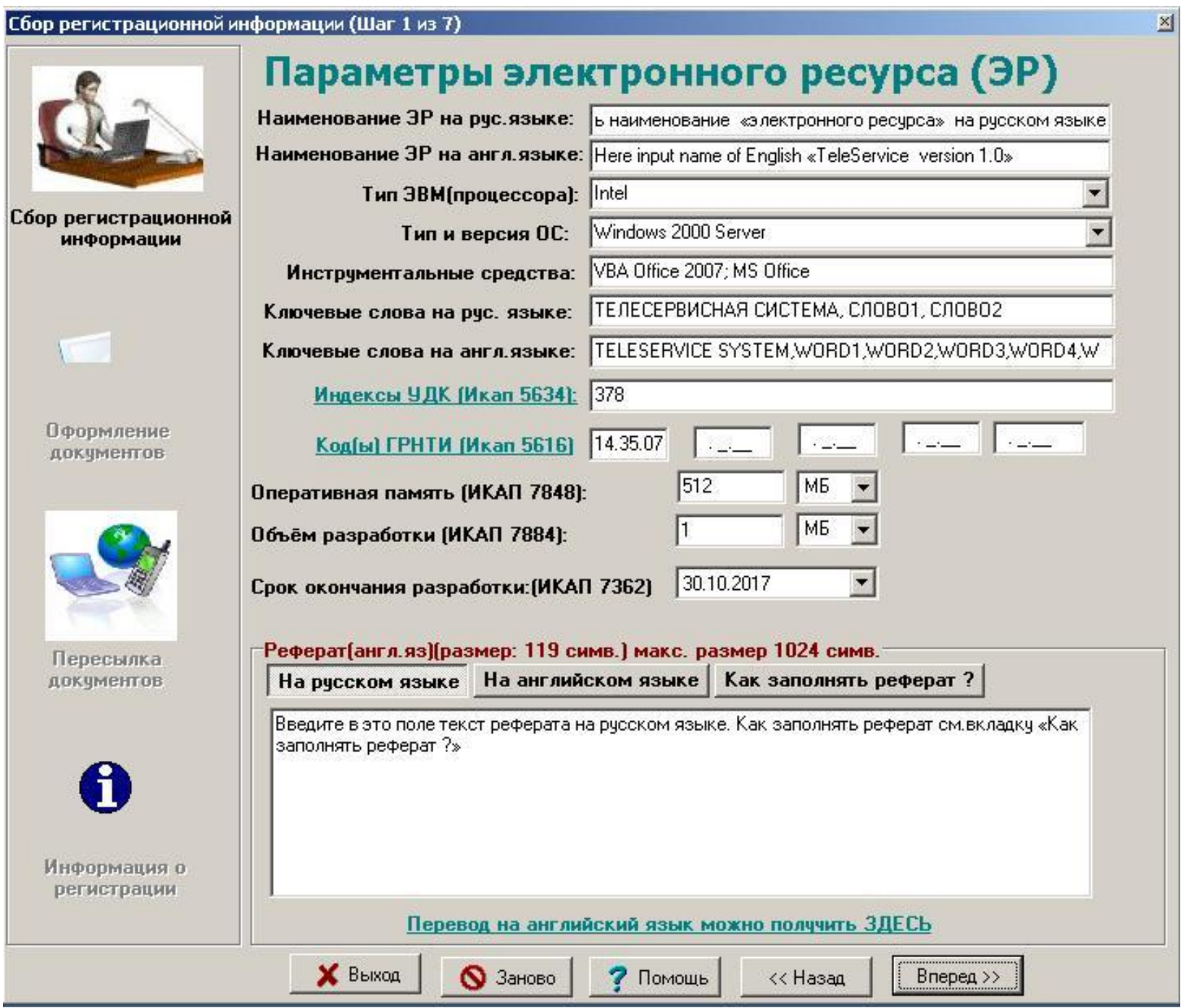

Рис. 9 Экран “Сбор регистрациионной информации (Шаг 1 из 7)” 


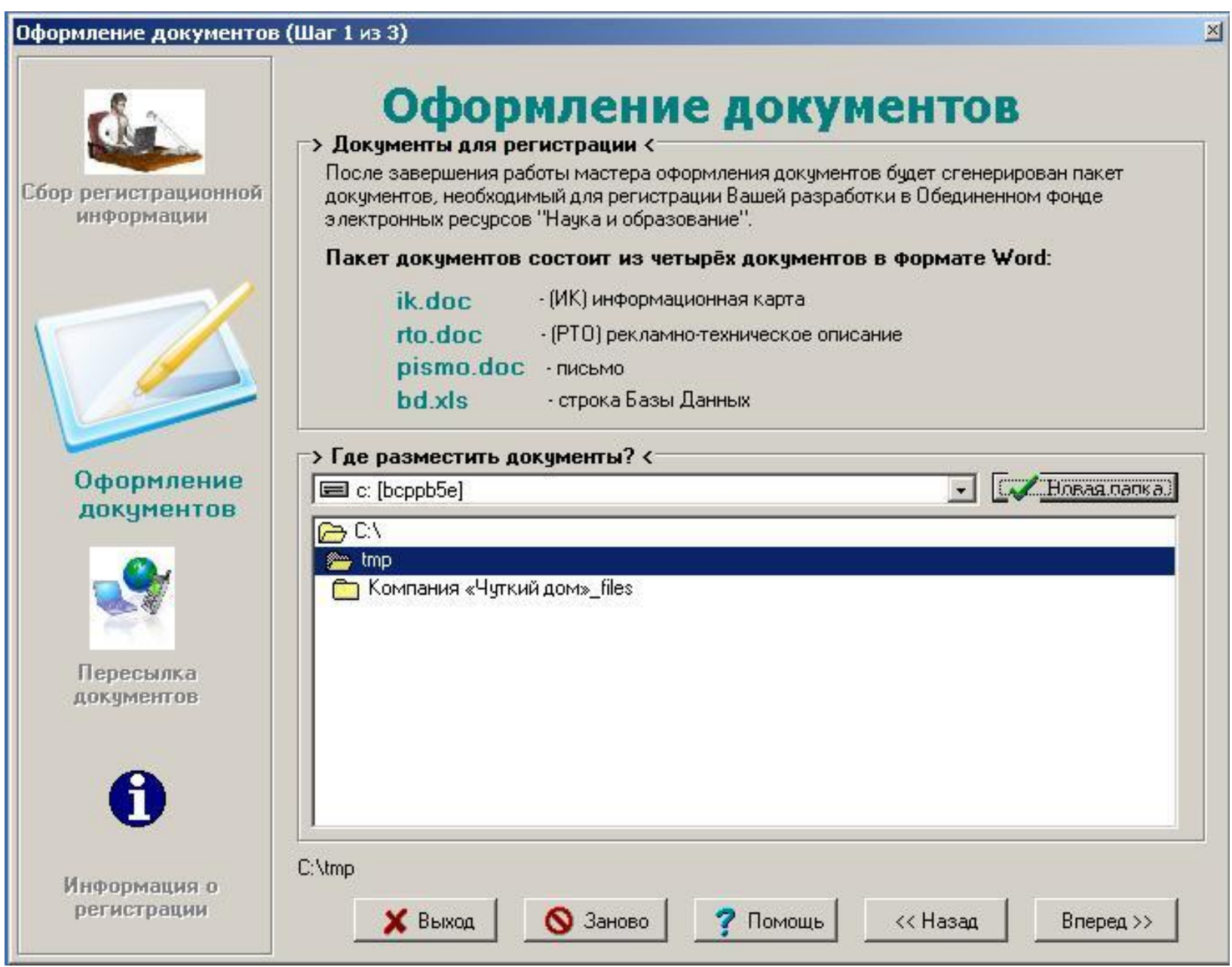

Рис. 10 Экран “Оформление документов (Шаг 1 из 3)” 
si.

Сбор регистрационной информацин

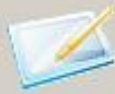

Dформление документов

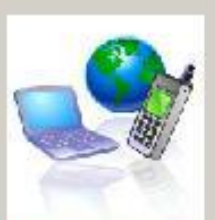

Пересылка документов

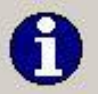

Информация о регистрации

\section{Спосо6 отправки}

Программа сгенерировала пакет электронных документов. необходимых для регистрации Вашей разработки в ОФЭРНиО. Теперь эти документы необходимо отправить специалистам ОФЭРНиО для проверки.

Выберите способ отправки электронных документов

С Через почтовый клиент [я отправло документы через свой почтовый клиент) Документы будут отправлены через используемую Вами почтовую программу [Outlook. The Bat! и т.д.). Для использования этого способа отправки Вы должны иметь возможность выхода в интернет и настроенную почтовую программу на этом компьютере.

С Автоматически [я хочу, чтобы программа сама отправила документы) Документы будат отправлен в 0中ЗРНи0 прямо сейчас, с этого компьютера через интернет. Для автоматической отправки документов необходимо иметь возможность выйти в интернет с этого компьютера. Если такой возможности нет, то документы можно отправить вручную.

6 Вручную [я хочу отправить все документы сам[-a])] Я сам[а] знаю как отправить файл-архив через почту которой я пользуюсь

Примечание:

Весь комплект документов упакован в архив формата ZIP, именно этот файл нужно отправить в 0中ЭРНиО

C: Itmp\0фЭРНи0_(Hockвa)_01236_RegOFERNiOV_3_3oт28_09_2017.zip

Х Выход Заново ? Помощь

Рис. 11 Экран “Пересылка документов (Шаг 1 из 2)” 


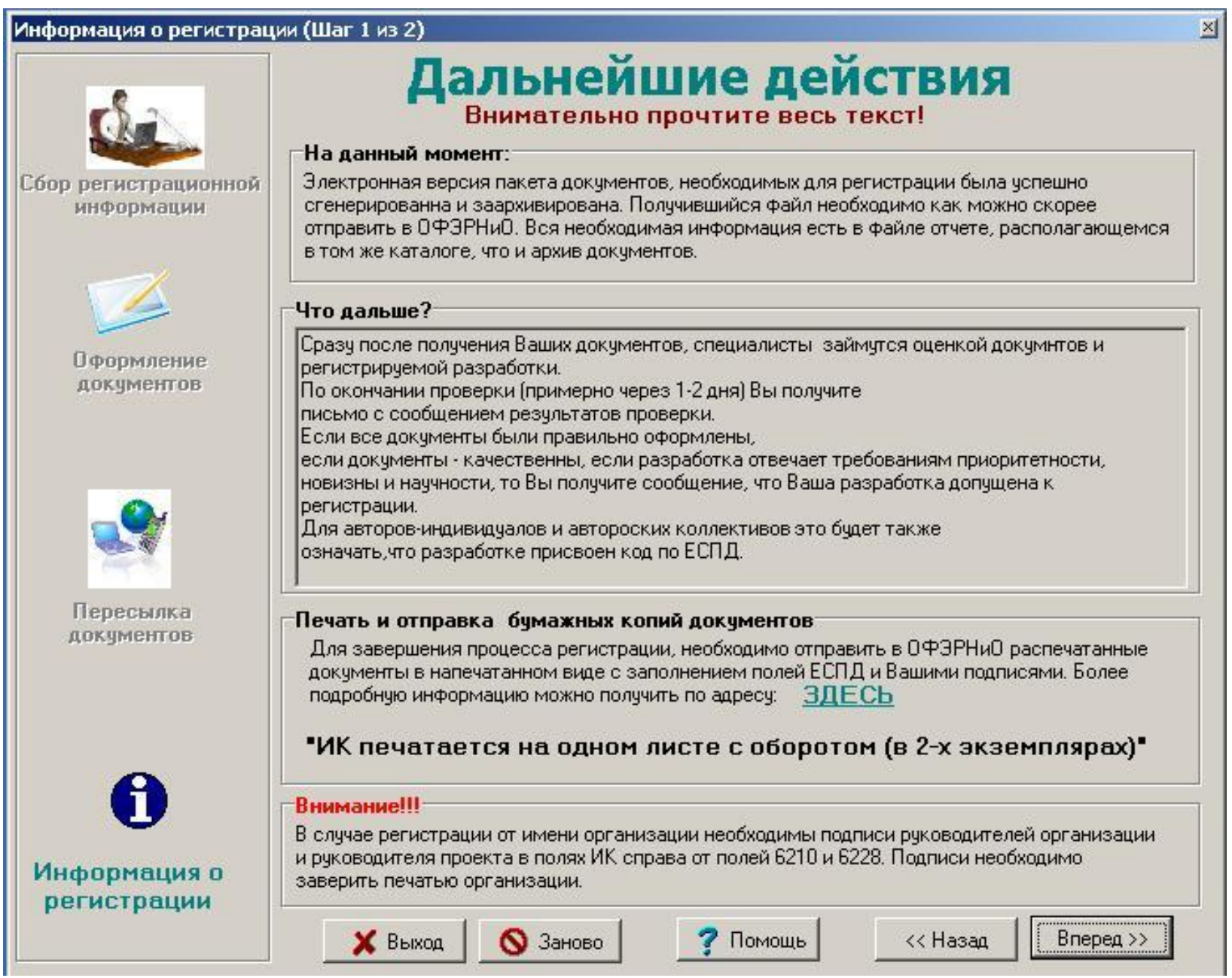

Рис. 9 Экран “Сбор регистрациионной информаџчи (Шаг 1 из 7)” 


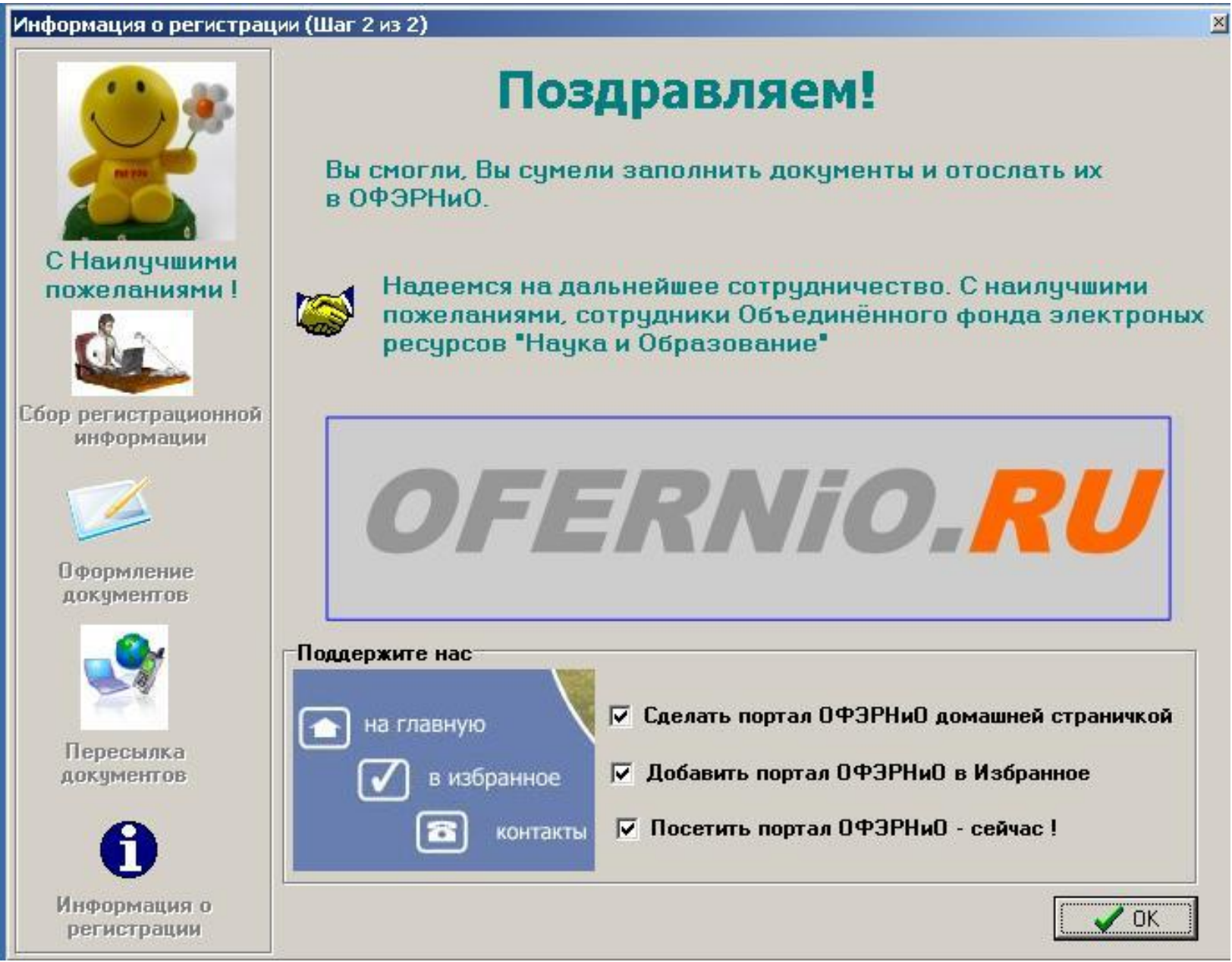

Рис. 12 Экран “Информащия о регистрации (Шаг 2 из 2)”

4.2. Для поиска аналогов рассматриваемого электронного образовательного ресурса необходимо обращчение $к$ Базе Данных ОФЭРНиО, которое осуществляется посредством Конструктора Запросов - web-форму на портале ОФЭРНиО по ссылке

http://www.ofernio.ru/program/ofapis_bd/query_sys_user.php? state=config 


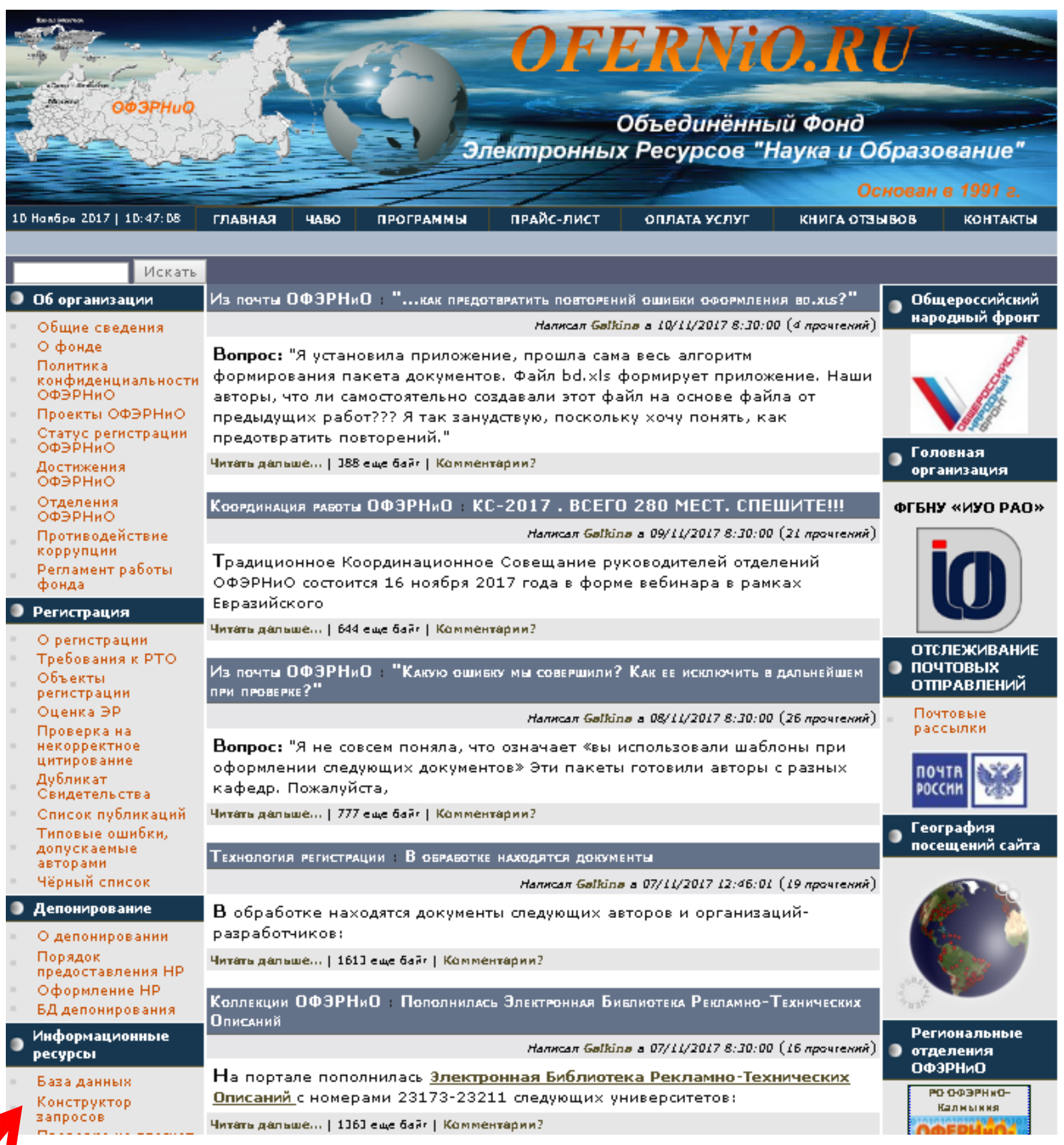

Рис. 13 Скриншот главной странищы портала с позищией размещения ссылки на КОНСТРУКТОР ЗАПРОСОВ

По ссылке открывается следующая форма Конструктора Запросов, через которую осуществляется запрос к БД ОФЭРНиО 
Главная страница :: Форма запроса :: Печать страницы :: Закрыть окно

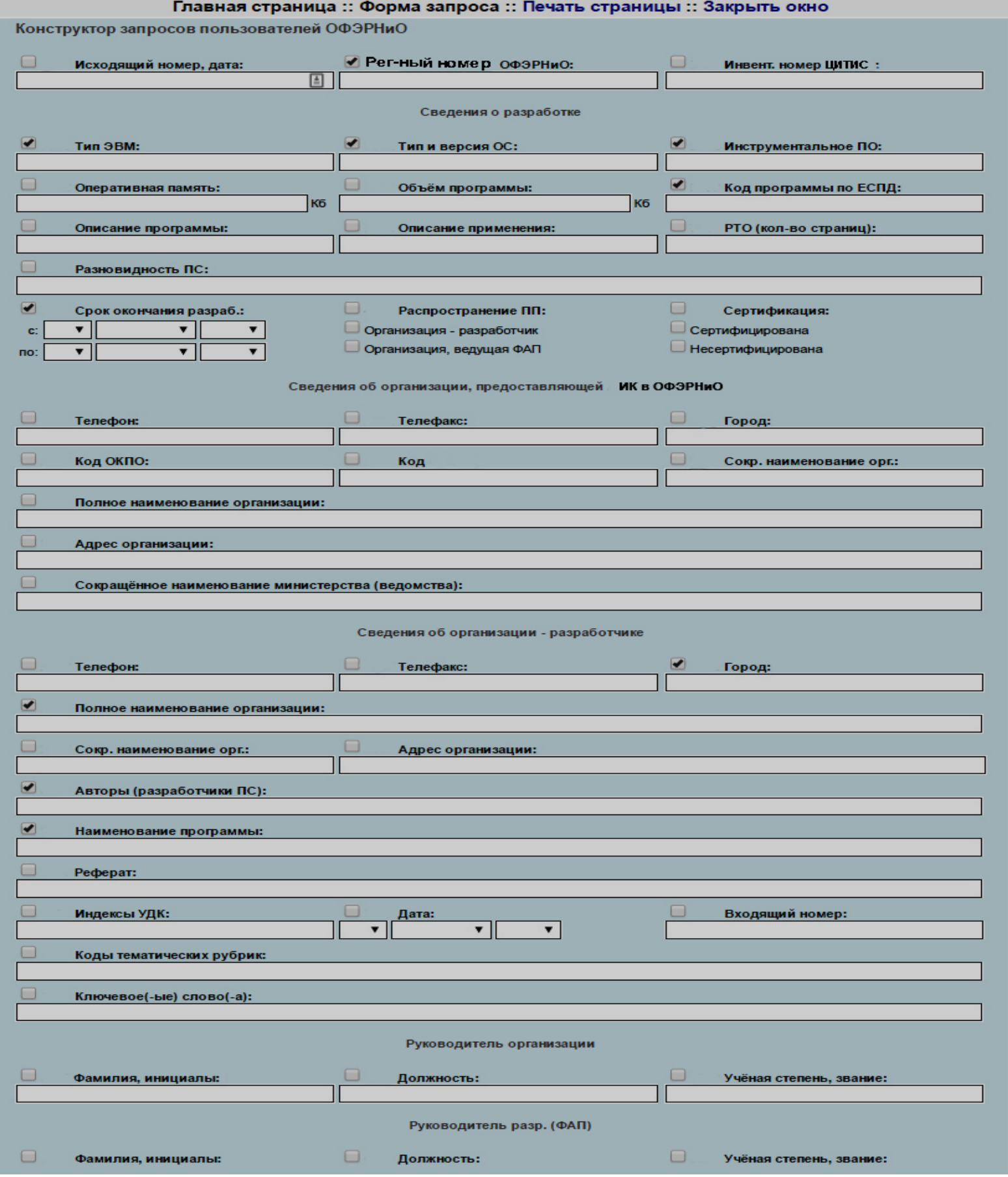

Рис. 14 Wеb-форма КОНСТРУКТОРА ЗАПРОСОВ (верхняя часть) 


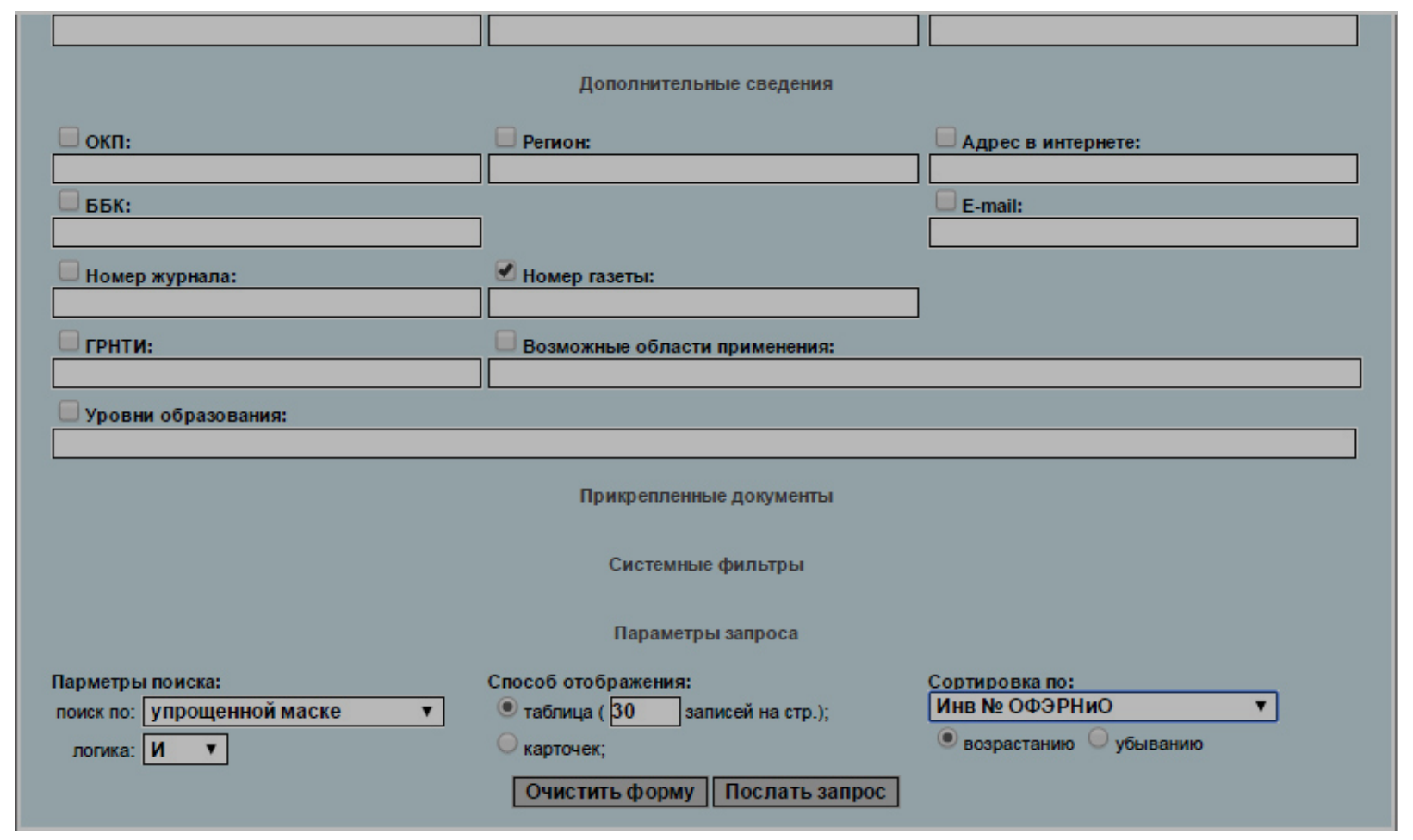

Рис. 14 Wеь-форма КОНСТРУКТОРА ЗАПРОСОВ (нижняя часть)

Поиск аналогов рассматриваемого электронного образовательного ресурса осуществляется в течение долей секунды и генерируется в форме таблицы или карточек. Hапример:

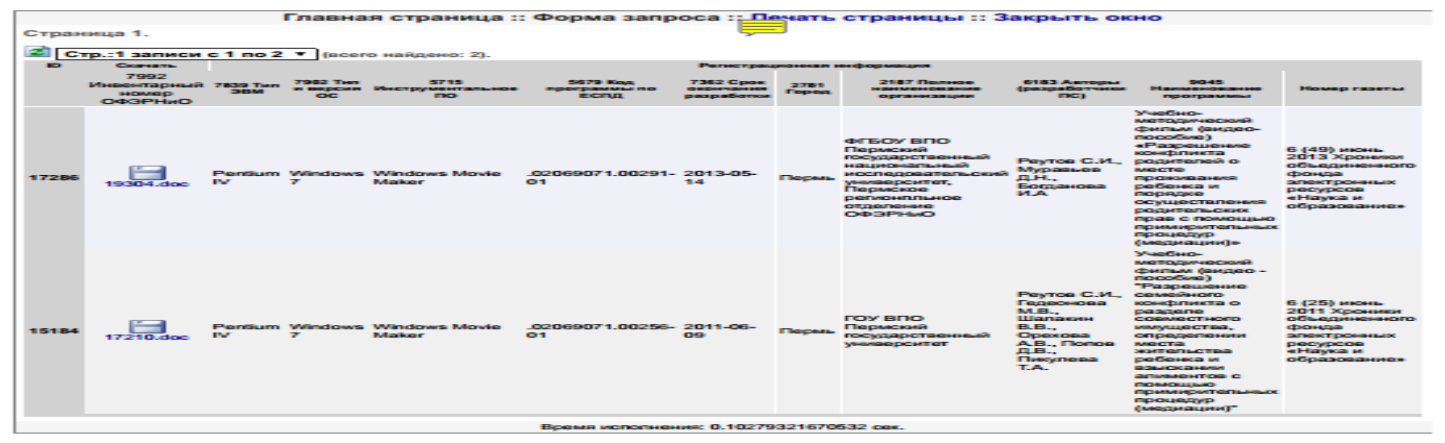

Рис. 15 Пример “Протокола БД” поиска аналога рассматриваемого ЭОР 
Отчет по поиску аналогов открывается в Foxit Reader в позиции Комментарий, фиксируется содержание запроса, время запроса, автор запроса, что подтверждает факт поиска аналогов (желтый значок - Комментарий).

4.3. Ресурс Антиплагиат https://www.antiplagiat.ru/cabinet

Ресурс используется для осуществления фискальной операции - оценки процента заимствований, используемых в документе Рекламно-Техническое Описание электронного образовательного ресурса, для подтверждения новизньи рассматриваемого электронного образовательного ресурса

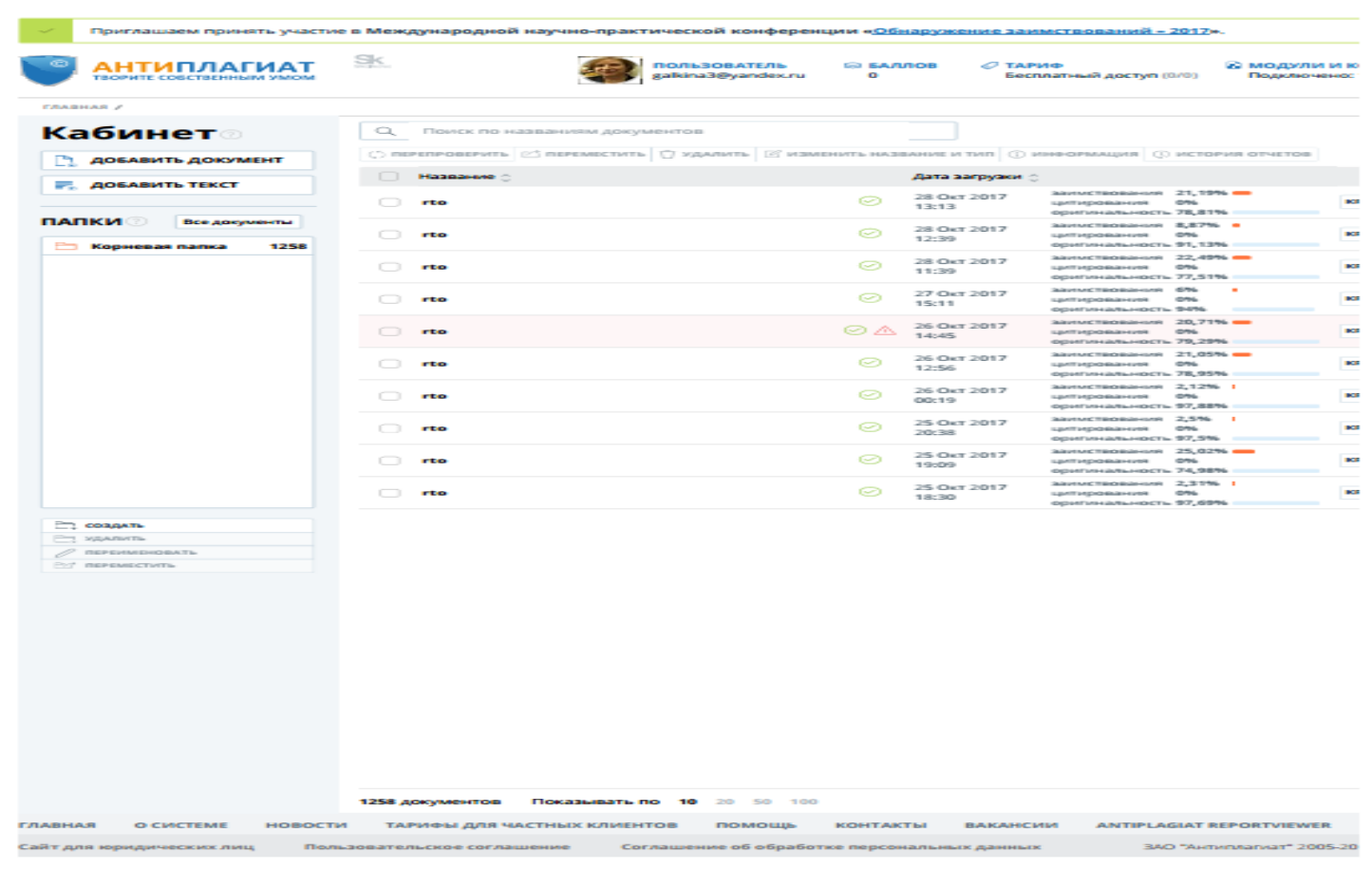

Рис. 16 Скриншот сайта АНТИПЛАГИАТ 


\section{5. Информационное обеспечение}

Главным информационным ресурсом ОФЭРНиО является его портал http://ofernio.ru/portal/modules/news/ , который был отмечен как победитель конкурсов РУНЕТ в 2005 и 2014 годах. Сегодня аудитория портала:

$\sqrt{ } 98$ стран мира;

$\sqrt{ } 82$ субъекта Российской Федерации;

$\sqrt{ } 745$ организаций и учреждений России;

$\sqrt{ }$ более 60000 авторов страны.

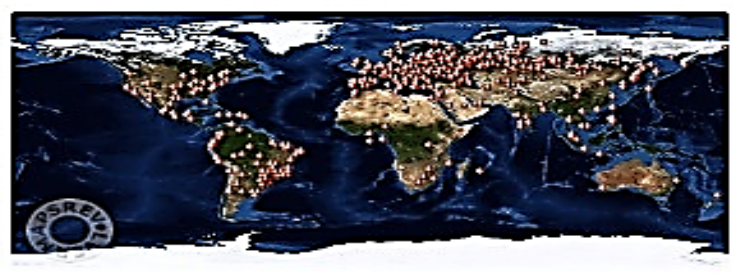

\section{Countries}

Vsits from 98 countries registered.
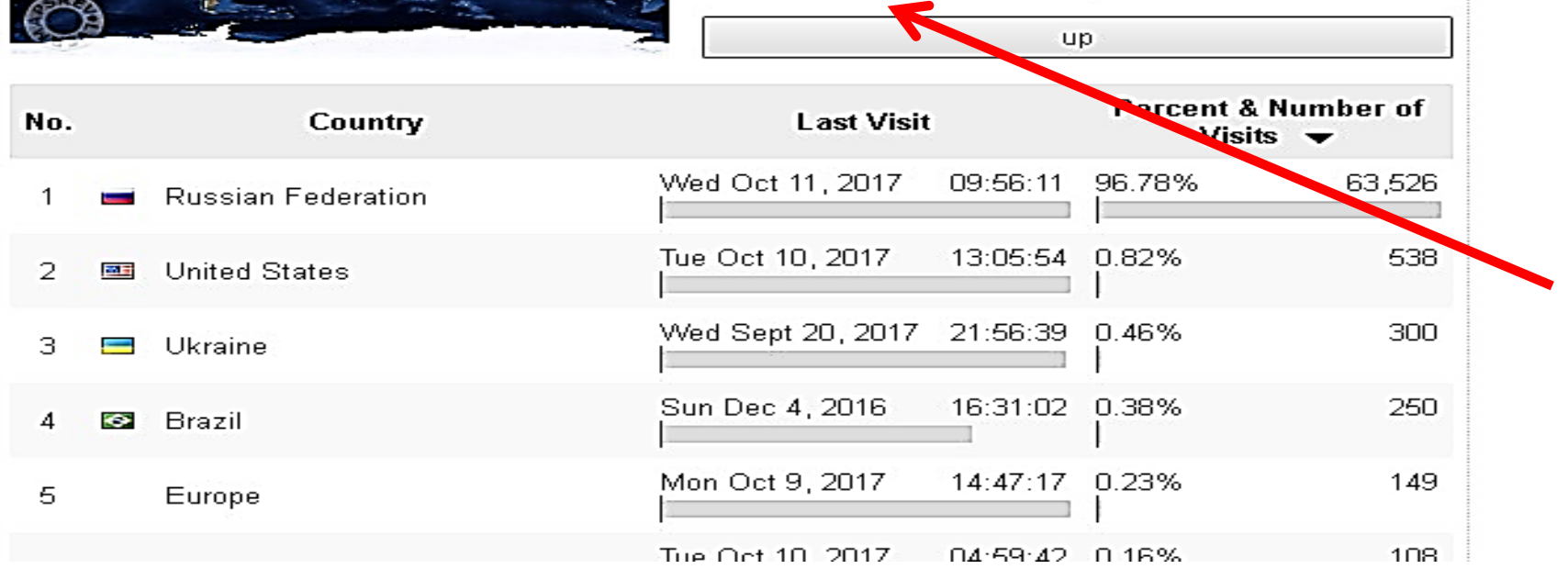

Рис. 17 География (статистика) посещений портала ОФЭРНиО в части субъектов мира 


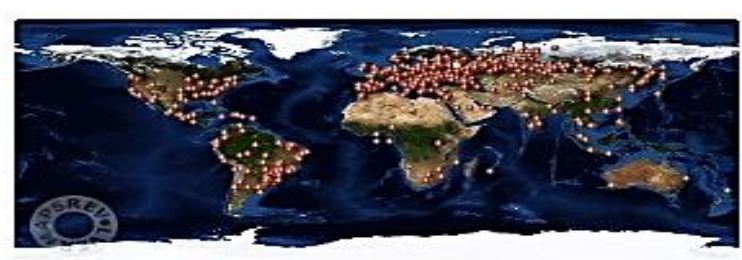

\section{Subdivisions}

$\begin{array}{ll}\text { No. } & \text { Subdivision } \\ 1 & \text { Moscow City } \\ 2 & \text { Yaroslavl } \\ 3 & \text { Omsk } \\ 4 & \text { Bashkortostan } \\ 5 & \text { Chelyabinsk } \\ 6 & \text { Rostov }\end{array}$

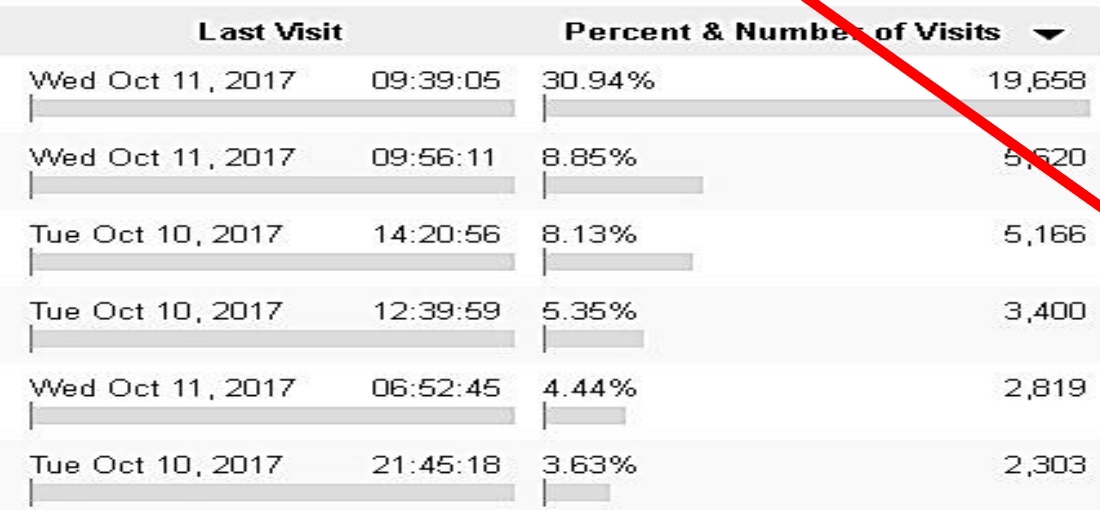

Рис. 18 География (статистика) посещеений портала ОФЭРНиО в части субъектов и авторов Российской Федерациии

Для оперативного оповещения научно-преподавательского сообщества о новинках в области ЭОР служит База Данных ОФЭРНиО (в открытом доступе), Библиотека Рекламно-Технических Описаний на портале ОФЭРНиО, но и издания фонда:

$\sqrt{ }$ сетевое издание (газета) «Хроники Объединенного фонд электронных ресурсов «Наука и образования»;

$\sqrt{ }$ сетевое издание (журнал) «Навигатор в мире науки и образования»;

$\sqrt{ }$ сетевое издание (журнал) "The navigator in the world of science and education»;

$\sqrt{ }$ электронное издание «Российские инициативные разработки (Инициатива.

Предприимчивость. Смекалка»)

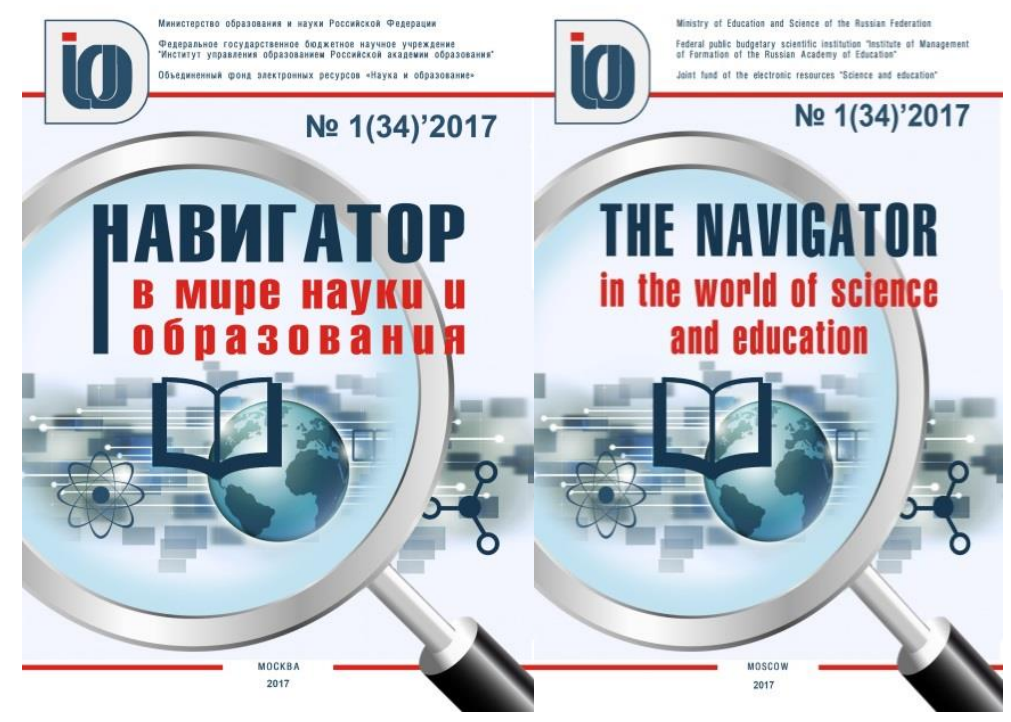

Рис. 19 Обложки сетевых изданий «Навигатор в мире науки и образования» $u$ «Тһе navigator in the world of science and education» 


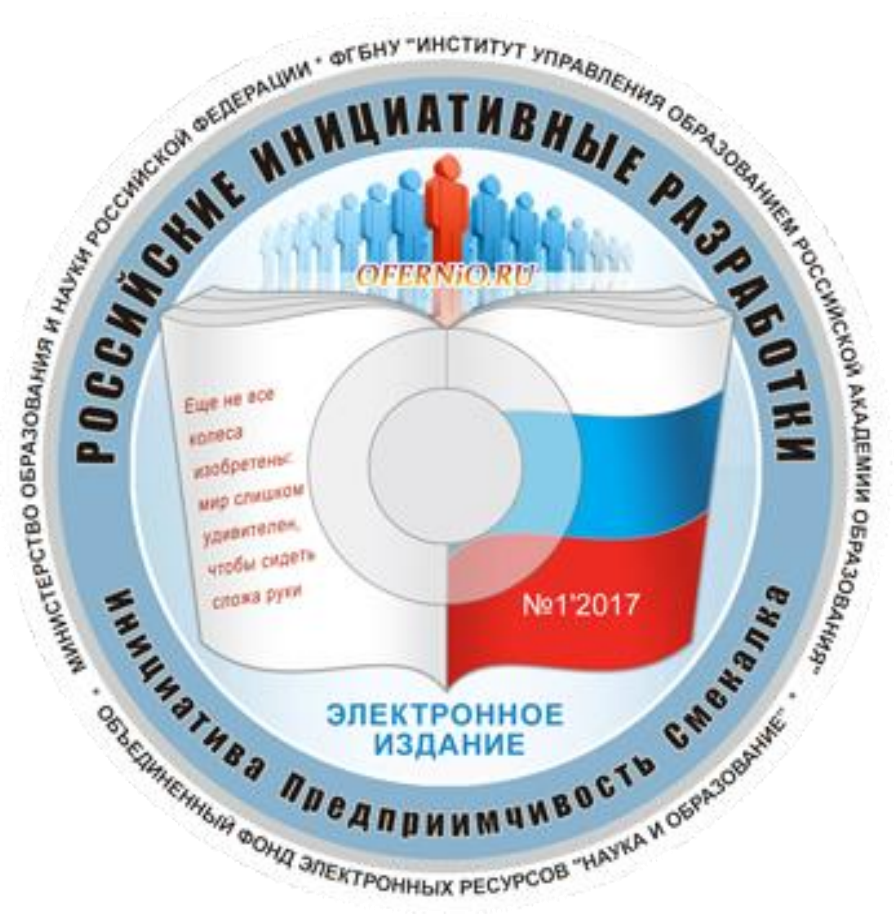

Рис. 20 Накатка электронного издания «Российские инициативные разработки (Инициатива. Предприимчивость. Смекалка)»

До 2009 года регистрация в ОФЭРНиО и публикация в изданиях фонда рассматривалась Высшей Аттестационной Комиссией как научная публикаџия и учитывалась при защите на ученую степень; учитывалась при присвоении ученого звания. Однако, с 2009 года ВАК уточнил определение научной публикации, рассматривая ее только как научную статью с ужесточением требований кее форме и содержанию.

До апреля 2017 года публикаџии в изданиях фонда, которые размещзались не только на портале фонда, но и в Научной Электронной Библиотеке, индексировались в Российской системе научного ичитирования (РИНЦ).

С апреля этого года Научная Электронная Библиотека ужесточила требования к научным изданиям и научным публикациям в части формы и содержания, индексируемых в РИНЦ. В этой ситуащии издания фонда, публикуюшие рекламно-технические описания, которые представляют собой электронные технические документы, будучи включенными в НЭБ, были исключены из ядра НЭБ и перестали индексироваться в РИНЦ.

На данном этапе развития проекта «Современная циифровая образовательная среда в Российской Федерации» востребована коммерциализация научных и образовательных учреждений с учетом прав на результаты интеллектуальной деятельности, в том числе на произведения науки в форме электронных образовательных ресурсов.

Стремясь зафиксировать результаты научно-педагогической деятельности в части разработки электронных образовательных ресурсов и закрепить авторские права на ЭОР, ОФЭРНиО принято стратегическое решение о присвоении доі всем ЭОР, 
регистрируемым в Объединенном фонде электронных ресурсов «Наука и образования» $и$ публикуемом на портале. 


\section{6. Пошаговая инструкция оценки электронного образовательного ресурса}

6.1. Открыть комплект документов, описывающих электронный образовательный ресурс: rto, pismo, $i k, b d-в$ указанном порядке

6.2. Провести оценку на полноту, достоверность, достаточность информации в документах; соответствия форм документов заявленной форме собственности; соответствие форм документов заявленной форме регистрации;

6.3. Проанализировать содержание документов и сформировать запрос к Базе Данных ОФЭРНиО

6.4. Внести компоненты запроса в соответствующие поля Конструктора Запросов, щелкнуть мышью по кнопке Послатьзапрос Получить отчет. Проанализировать отчет.

6.5. В случае наличия аналогов рассматриваемого электронного образовательного ресурса провести анализ и сравнение ориентированнопотребительских характеристик рассматриваемого электронного образовательного ресурса и аналога в следующем порядке:

- Программно-технические характеристики. Если характеристики аналогичные, переходим к оценке Эргономических характеристик. Если характеристики разные переходим к пункту 6.6.

- Эргономические характеристики. Если характеристики одинаковые, переходим к рассмотрению Психолого-Педагогических характеристик. Если характеристики разные переходим к пункту 6.6.

- Психолого-Педагогические характеристики. Если характеристики одинаковые, делаем вывод об отсутствии новизны электронного образовательного ресурса и невозможности его регистрации в ОФЭРНиО. Если характеристики разнье переходим к пункту 6.6.

В случае отсутствия аналогов рассматриваемого электронного ресурса переходим к пункту 6.6.

6.6. Переходим на сайm https://www.antiplagiat.ru и осуществляем фискальную операцию, по проверке текста Рекламно-Технического Описания рассматриваемого электронного образовательного ресурса. Загружаем документ rto. Запускаем проверку по позищии Сетевые ресурсы. При наличии показателя ОРИГИНАЛЬНОСТЬ ниже 70\% , формируем отказ в регистрачии. 


\section{Список литературы}

1. Неустроев С.С., Предыбайло В.А., Галкина А.И., Бурнашева Е.А., Гришан И.А РОССИЙСКИЕ ИНИЦИАТИВНЫЕ РАЗРАБОТКИ (ИНИЦИАТИВА. ПРЕДПРИИМЧИВОСТЬ. СМЕКАЛКА) Научное издание / - Saint-Louis, Missouri, USA: Science and Innovation Center Publishing House, 2017-2017, C. 112 DOI: 10.12731/DEVELOPMENT.2017.110

2. Галкина А.И. АКТУАЛЬНЫЕ ВОПРОСЫ РЕГИСТРАЦИИ МЕДИЦИНСКИХ ЭЛЕКТРОННЫХ ОБРАЗОВАТЕЛЬНЫХ РЕСУРСОВ В УСЛОВИЯХ МОДЕРНИЗАЦИИ МЕДИЦИНСКОГО ОБРАЗОВАНИЯ / СовременнЫе технологии в науке и образовании - СТНО-2017 сборник трудов II Международной научно-технической и научно-методической конференции: в 8 т. Рязанский государственный радиотехнический университет. 2017. С. 138-143. 0

3. ГалКИна А.И.ЭЛЕКТРОННЫЕ ОБРАЗОВАТЕЛЬНЫЕ РЕСУРСЫ - КАК ПОКАЗАТЕЛЬ МОНИТОРИНГА ВУЗОВ/ ЕКаТеринбург: ФГБОУ ВО РГППУ// Новые информационные технологии в образовании и науке Материалы X международной научно-практической конференции. 2017. С. 51-55. 0

4. Galkina A.I., Bobkova E.Yu., Burnasheva E.A., Grishan I.A. REPUTATIONAL MANAGEMENT OF UNIVERSITIES, AS PARTICIPANTS IN THE VOCATIONAL GUIDANCE SYSTEM / Саратов: ПАРАДИГМА //Modern approaches to the management of economic systems in the conditions of global transformation Proceedings of the III International scientific and practical conference. 2017. C. 92-101. 1

5. Галкина А.И., Бобкова Е.Ю., Бурнашева Е.А., Гришан И.А. ПРОБЛЕМЫ ОЦЕНКИ НОВИЗНЫ ПРОИЗВЕДЕНИЙ НАУКИ В ФОРМЕ ЭЛЕКТРОННЫХ ОБРАЗОВАТЕЛЬНЫХ РЕСУРСОВ/ М.: ГНИИ ИТТ “ИНформика" //Информатизация образования и науки. 2017. № 3 (35). С. 145-156. 1

6. Неустроев С.С., Предьюбайло В.А., Галкина А.И., Бобкова Е.Ю., Бурнашева Е.А., Гришан И.А.ОТРАСЛЕВАЯ РЕГИСТРАЦИЯ РИД КАК ИНСТРУМЕНТ УПРАВЛЕНИЯ СФЕРОЙ ОБРАЗОВАНИЯ НА РУБЕЖЕ ХХ-ХХІ ВЕКОВ ( ЩРОБЛЕМЫ АВТОРСКОГО ПРАВА НА РИД В СФЕРЕ НАУКИ И ОБРАЗОВАНИЯ В КОНЦЕ ХХ-ХХІ ВЕКА») / М.: РАЕ //Международный журнал экспериментального образования. 2017. № 3-2. С. 222-223.

7. Галкина А.И., Бобкова Е.Ю., Бурнашева Е.А., Гришан И.А., Кадырова Э.А. ИНФОРМАЦИОННЫЕ РЕСУРСЫ ОФЭРНИО КАК ЭФФЕКТИВНЫЙ ИНСТРУМЕНТ МЕНЕДЖМЕНТА СИСТЕМЫ ОБРАЗОВАНИЯ /БрянсК: ФГБОУ ВО БГТТА //Экономика и эффективность организации производства. 2017. № 25. C. 54-57.

8. Галкина А.И., Бобкова Е.Ю., Бурнашева Е.А., Гришан И.А. РЕПУТАЦИОННЫЙ МЕНЕДЖМЕНТ ВУЗОВ, КАК УЧАСТНИКОВ СИСТЕМЫ ПРОФЕССИОНАЛЬНОЙ ОРИЕНТАЦИИ СараТОВ: НИИ ПАРАДИГМА // сборник конференции «Профессиональная ориентация». 2017. № 1. С. 55-65. 
9. ГалКИна А.И.МОДЕЛЬ ОТРАСЛЕВОЙ ТЕХНОЛОГИИ ОЦЕНКИ КАЧЕСТВА ПРОИЗВЕДЕНИЙ НАУКИ В ФОРМЕ ЭЛЕКТРОННЫХ ОБРАЗОВАТЕЛЬНЫХ РЕСУРСОВ / Нижневартовск - Бюллетень науки и практики. 2017. № 10 (23). С. 344-357.

10. Галкина А.И., Бурнашева Е.А., Гришан И.А. МОНИТОРИНГ РОССИЙСКИХ УНИВЕРСИТЕТОВ: НАСТОЯЩЕЕ И БУДУЩЕЕ / Нижневартовск - БюлЛетень науки и практики. 2017. № 9 (22). С. 215-231.

11. ГалКИна А.И.МОДЕЛЬ ОЦЕНКИ КАЧЕСТВА ПРОИЗВЕДЕНИЙ НАУКИ В ФОРМЕ ЭЛЕКТРОННЫХ ОБРАЗОВАТЕЛЬНЫХ РЕСУРСОВ / Нижневартовск Бюллетень науки и практики. 2017. № 9 (22). С. 232-238. 
Scientific publication

Галкина А.И., Бобкова Е.Ю., Бурнашева Е.А., Гришан И.А., Кадырова Э.А.

Методологический инструментарий оценки новизны произведений науки в форме электронных образовательных ресурсов

Методические указания

Issue is published in author's edition

Assigned to print 29.10.2017. Format 60x84 1/16.

CPP 3. Order OR2910. Circulation 500.

Publisher:

Science and Innovation Center Publishing House

S. Jefferson Str, Saint Louis, Missouri, 63118, USA

Printed in the USA 
